\title{
Revisiting port system delineation through an analysis of maritime interdependencies among seaports
}

\author{
César Ducruet \\ French National Centre for Scientific Research (CNRS) \\ Paris, France \\ $\underline{\text { cdu@ parisgeo.cnrs.fr }}$ \\ Theo E. Notteboom \\ CEMIL, China Institute of FTZ Supply Chain, Shanghai Maritime University, China \\ Maritime Institute, Faculty of Law and Criminology, Ghent University, Belgium \\ Faculty of Applied Economics, University of Antwerp, Belgium \\ Antwerp Maritime Academy, Belgium \\ theo.notteboom@gmail.com
}
Pre-final version of the article published in Geojournal (2020)
https://doi.org/10.1007/s10708-020-10341-x

\begin{abstract}
A port system is a system of two or more ports, located in proximity within a given area. In literature, various geographical and functional scales have been identified ranging from complete coastlines to the notions of a 'range' and a 'multi-port gateway region'. Not only does the spatial scale create confusion on the true functional delineation of port systems, but it also complicates a clear understanding of the relational mechanisms at stake within these port systems. This paper revisits existing approaches to and empirical delineations of port systems. Maritime network analysis techniques are deployed to understand hierarchies and interdependencies among nodes of container port systems and sub-systems in North Europe and Northeast Asia. The results provide additional insights on how ports interact from a maritime services' perspectives and demonstrate whether or not ports which are traditionally considered as belonging to the same port system can in reality be considered forming a fully integrated port system.
\end{abstract}

Keywords: connectivity; port geography, port system, maritime network 


\section{Introduction}

In transport geography and beyond, the analysis of ports has long resulted in scattered monographs interested in the morphological evolution of their infrastructure and outlying territory (for a review of port geography research see $\mathrm{Ng}$ and Ducruet, 2014 and $\mathrm{Ng}$ et al., 2014). Model-based approaches were soon proposed to grasp ideal-typical sequences of port development, not only at the level of the port itself but more transnational in scope, as in the famous corridor development model of Taaffe et al. (1963) that pioneered the study of what would become the concept of a "port system". While this model was greatly inspired from the formation of urban primacy in developing economies, other works on coastal corridor development were highly influential for subsequent research on ports, such as on the Northeastern U.S. megalopolis from Boston to Washington (Gottmann, 1961) and the North European port range from Le Havre to Hamburg (Vigarié, 1964). Those studies had in common that they considered port development from a strict land-based perspective. This was criticized at the same period by Rimmer (1967) in his study of Oceania, calling for the inclusion of maritime linkages in the study of port systems. This posture was only adopted by Robinson (1968) in his $\mathrm{PhD}$ dissertation on Vancouver and British Columbia ports, before maritime network analysis started to receive foremost attention from the 2000s onwards (see Ducruet, 2020 for a recent review).

Another characteristic of port system analysis was its preoccupation with small sets of ports within national boundaries (see a review by Ducruet et al., 2009a). This dominant approach illustrated the belief that port systems mainly rest on geographic proximity and political borders. The definition - and thus the delineation - of port systems varies greatly across the academic spectrum, and is often confounded with a coast, a country, a range or maritime façade, and to a wider entity from seas and basins to the entire world port system. In a review of no less than 399 port geography papers, Mareï and Ducruet (2015) concluded that a majority (48\%) of this corpus studied a single port, $22 \%$ focused at the country level, $10.3 \%$ at the subnational scale, $13.5 \%$ opted for a transnational approach, and less than $1 \%$ concerned the level of entire basins, while the world level only occupied $5.5 \%$ of all papers.

Not only does the spatial scale create confusion on the true functional delineation of port systems, but it also complicates a clear understanding of the relational mechanisms at stake within the port system itself. It is a fact that the prime interest of scholars studying port systems is the way ports dominate each other. Methodologically, such analyses look at the distribution of port throughputs and its evolution through markets shares or more advanced statistical methods like the application of the Gini coefficient or the Herfindahl index. Yet and as underlined long ago by Rimmer (1967), the relational approach is ignored in classical studies of port systems, or the way ports are actually linked with each other through the maritime 
network, as highlighted by Robinson (1968, pp. 95-97): "it is possible to define the spatial patterns of functional relationships between ports by examining the linkages which are sustained by the inter-port shipping movements of foreign trade vessels. Such an analysis provides not only an accurate measure of the linkages themselves but also clarifies the relationships between ports, the spatial organization of port functions and the functional status of individual ports within the total group (...) The system of ports operating interdependently may now be regarded in abstract form as a set of points or nodes in a network, a transportation network in which the lines or links in the network are in fact 'imaginary routes". The relational perspective thus serves to identify not only hierarchies but functions within the port system.

Much later, the further integration of graph theory and complex network methods into port geography shall revive Robinson's legacy (but without reference to it). Concepts of hub, bridge and community gradually became rather common in maritime network studies, benefitting from increasingly available shipping data on inter-port flows and improved computational power. New models of network development were proposed in maritime studies, exactly by Robinson (1998) three decades later, proposing to consider the multilayered nature of hub hierarchies in Asia and elsewhere.

At present, an important number of port system studies is in hand to attempt a review of the field. This paper wishes to examine how existing delineations of port systems correspond to the pattern of maritime flows, based on the case of container shipping. We compare the distribution of port hierarchies and inter-port maritime flows within two regions, namely North Europe and Northeast Asia, for the years 1996, 2006, and 2016. These two regions with cargorich hinterlands are among the most important port areas in the world in volume terms. For example, eight of the ten largest container ports in the world (in TEU terms) are located in Northeast Asia, while 6 of the top 10 container ports in Europe are located in North Europe, including the top 3, i.e. Rotterdam, Antwerp and Hamburg. Furthermore, many of these ports are leading the way in terms of port business innovation (Merk, 2013), green port development (Lam and Notteboom, 2014) and efficient and effective port governance (see e.g. the edited volume by Brooks et al., 2017). Given their status at the global port scene, their highly dynamic development paths and observed dynamics in inter-port competition and co-operation, these regions have attracted considerable attention from transport specialists willing to study port systems, should it be at the level of the entire regions or at thinner geographic levels. Despite extensive studies on these port regions or parts thereof, some key questions related to the spatiotemporal dynamics in port systems remain underexplored. How are existing definitions / visions of port systems reflected in the actual pattern of maritime flows and ship calling patterns? What are the implications of matches or gaps between the two for research and practice/policy? Our main hypothesis is that ports should be coupled/strongly interconnected 
based on carrier choices but also other factors (geography, range effects, hubs and spokes), resulting in possible discrepancies between commonly accepted port systems and actual ones.

This paper thus revisits existing approaches to and empirical delineations of port systems. In particular, maritime network analysis techniques are deployed to understand hierarchies and interdependencies among nodes of container port systems and sub-systems in North Europe and Northeast Asia. As such, it is close to existing graph-theoretical works willing to test the overlap between a system of flows and given borders. The work of Blondel et al. (2010) on mobile phone telecommunications in Belgium, for instance, can be seen as a pioneering experiment of the kind, revealing the extent to which such communications are influenced by cultural and administrative borders. The results provide additional insights on how ports interact from a maritime services' perspective and demonstrate whether or not ports which are traditionally considered as belonging to the same port system can in reality be considered to be a fully integrated port system. We thus check how the decomposed maritime network corresponds to existing port system delineations, and discuss the factors causing gaps or overlaps.

The remainder of this paper is organized as follows. Section 2 reviews how port systems have been treated in the literature in general and more specifically about North Europe and Northeast Asia, providing a typology of existing studies. This literature review sets the background for a confrontation with our empirical results. Section 3 includes a quantitative analysis of vessel movement data in view of unravelling the maritime backbone and port communities of the two regions under examination in a comparative and dynamic perspective. We discuss in Section 4 the degree of overlap between our results and existing port system delineations and present conclusions about the lessons learned for further research in the field.

\section{The concept 'port system' in literature}

A port system can be defined as a system of two or more ports, located in proximity within a given area (Ducruet, 2009). In literature, various geographical and functional scales have been identified ranging from complete coastlines (e.g. the West coast of North America as one port system) to the notion of a 'range' (Vigarié, 1964) and a 'multi-port gateway region'. A port range can be defined as a group of container ports situated along the same seashore and sharing 
more or less the inland service area (i.e. a shared or overlapping hinterland). A commonly used example is the Hamburg-Le Havre range in Europe. Within container port ranges one can generally observe fierce intra-range competition. A multi-port gateway region refers to a smaller geographical scale then a container port range. The term was first coined by Notteboom (2009a; 2010) and later also applied by e.g. Feng and Notteboom (2013) and Liu et al (2013). The locational relationship to nearby identical traffic hinterlands is one of the criteria that can be used to group adjacent container ports into the same multi-port gateway region. Also, the port calling patterns in the liner service networks of shipping and hinterland connectivity profile can help to group ports to a multi-port gateway region (Notteboom, 2009). Typical examples include the Rhine-Scheldt Delta (Belgium and the Netherlands) and the Yangtze River Delta and Pearl River Delta in China. A container port range can be home to several multi-port gateway regions. For example, the Hamburg-Le Havre range includes the multi-port gateway regions of North-Germany, the Rhine-Scheldt Delta and the Seine Estuary in France.

Tables 1 and 2 provide an overview of studies focusing on different scales of container port systems (i.e. continent-wide port systems, ranges and multi-port gateway regions) in respectively North Europe and East Asia. Next to the identification of the container port systems analysed, the tables also classify extant literature based on the main methodological approaches deployed by the respective authors. Thereby, a distinction is made between the following research dimensions:

- Studies focusing on the analysis of container traffic volumes and related market shares within the given port systems;

- Studies using measures to analyse container traffic (de)concentration patterns in port systems. Most of these port geography papers rely on measures of concentration or inequality such as the Gini coefficient (including Lorenz curves and Gini decomposition analysis) and the Herfindahl-Hirschman Index (HHI);

- Studies relying on maritime network analysis deploying a wide range of network indicators and measures linked to the centrality and connectivity of nodes within a maritime network consisting of container liner services;

- Port choice and port competitiveness studies. Here, logit models, decision making models (such as Analytical Hierarchy Process - AHP), factor analysis, principal component analysis or other statistical techniques are used to analyse the relative competitiveness of a 
node within a given container port system or to model route and port choice through a port system;

- Analysis of complementarity vs. substitutability between ports. Here, the focus is on assessing whether nodes of the same port system act as substitutes to each other (implying competition) or complements (pointing to a high level of interdependence among the nodes);

- Determination of the 'relevant geographic market' (RGM). The term RGM typically is used by competition authorities to assess changes in the power of market actors in case of a merger or acquisition. The RGM can be defined as a geographical territory in which competition conditions in a relevant market of a product or service are sufficiently the same for all participants and therefore this territory can be separated from other territories. In a port context, the RGM concept has mainly been used to assess the impact of an M\&A (mergers and acquisitions) activity in the container terminal operating business on the market positions of terminal operators. A well-known and pioneering EC competition case in the port sector was the take-over of ECT in Rotterdam by HutchisonPorts in the late 1990s;

- Traffic forecasting studies which deploy time series analysis and more advanced forecasting methods to develop scenarios and prognoses for the future traffic volumes and related market shares of nodes in a port system.

Table 1 Overview of port system studies focusing on container ports in North Europe Table 2 Overview of port system studies focusing on container ports in East Asia

Tables 1 and 2 show that diverse delineations of container port systems have been used, while Figure 1 provides a cartography of the most recurrent configurations. The port range is the most common geographical scale of analysis. In North Europe, the Hamburg-Le Havre range is the most used port range, while the entire Scandinavia/Baltic region is typically considered as one port range. The same applies to the UK/Ireland. In East Asia, a much broader set of possible delineations of port ranges is used. Some of these delineations follow a country-based 
approach (e.g. port systems in South Korea and Japan) while in other cases the considered range follows a more functional definition less based on administrative borders.

A limited number of studies focus on multi-port gateway regions. In East Asia, the Pearl River Delta and Yangtze River Delta are frequently examined multi-port gateway regions, although in other studies these deltas are considered as port ranges. The Bohai Rim in the northeast of China (also known as the Bohai Sea Economic Rim) is sometimes assessed as one port system at range or gateway region level, while in other studies the region is further decomposed in several sub-systems such as the Liaoning port system, Shandong port system and the Jin-Ji system (near Tianjin and Beijing). The most commonly used delineations of gateway regions in North Europe include the Rhine-Scheldt Delta, the Seine Estuary and the north German port system, all belonging to the Hamburg-Le Havre range. However, the ports included in these multi-port gateway regions might differ among the studies observed. For example, in Notteboom (2010), Dunkirk (France) and Amsterdam are included in the Rhine-Scheldt Delta while other studies follow a narrower delineation of this delta by only including ports which are located along or in the estuaries of the rivers Rhine/Meuse/Scheldt.

The reported studies each focus on specific functional interdependencies among nodes of the port systems under consideration which makes the delineation of relevant port systems and sub-systems more complex. In line with the work of Van Klink (1995), seaports can be subjected to three types of functional interdependencies with other nodes of the same port system:

- Chain networks. The output of one port in the system is the input for another. Trans-oceanic relations are an example of chain networks (e.g. relation Rotterdam - Singapore for deepsea liner services on the Europe-Far East trade);

- Complex networks. The nodes use each other's output. An example are the relations between ports in a hub-and-spoke network setting (e.g. South Korean container port Busan and smaller feeder ports in Northeast Asia).

- Formation networks. The formation network is based on pooled relations. The ports in the system make use of the same location factors. In these relations, competition but also complementarity/co-operation among ports can occur. 
The vast majority of the studies mentioned in Tables 1 and 2 assess port systems by addressing competition and cargo concentration or deconcentration between nodes in the same formation network. Port choice and traffic forecasting studies (and related market shares) are also based on the interaction of ports in a formation network. The same applies to the notion of 'relevant geographic market' used by competition authorities.

Maritime network analyses, however, look at the interaction between nodes also in chain and complex networks. In fact, the study of maritime networks allows to develop a dual approach to the analysis and delineation of port systems. First, one can identify sub-systems of a large port system which basically act separately from each other (separate sub-markets from a maritime perspective). Second, one can identify sub-sets or groups of ports within a wider port system with a high complementarity and interdependence and which compete with other such groups.

The analysis of maritime networks thus allows to assess hierarchies and interdependencies among nodes in a port system. However, the position and function of a seaport in such a port system is only examined from the perspective of maritime liner services and related maritime connectivity without considering the spatial and functional ties seaports have with the land leg, i.e. potential overlaps or complementarity in hinterland coverage (i.e. shared / contestable / overlapping hinterland vs. captive hinterland). Thus, the delineations of port systems using maritime network analysis solely focus on maritime liner services. Still, such analysis can provide additional insights on the validity of the use of specific port system delineations used in literature while also adding chain and complex network dimensions to the more traditional formation network approach.

\section{Maritime interdependencies among seaports in North Europe and Northeast Asia}

\subsection{Methodology}

3.1.1 Data and network construction 
In this paper, we use Lloyd's List global database on vessel movements among ports of the world. This source has advantages and disadvantages for the analysis of maritime networks. On the one hand, it is highly representative of this particular shipping segment as it covers the entire fleet of containerships. It is also very detailed as it provides the carrying capacity, flag, operator, date of build, and the dates of arrival and departure of each vessel. On the other, what remains unknown is the true amount of cargo carried by vessels and therefore handled at the docks. In any case, it allows to construct a global, weighted origin-destination matrix of container flows following the methodology used by Hu and Zhu (2009) based on liner schedule and port call data. From this methodology, we opted for the space-P topology where all ports visited by the same vessel during a certain time period (here four complete months of circulation per year of observation, i.e. May-June and November-December) are connected within a complete subgraph. All subgraphs are combined to form the final network made of all vessel movements between all ports. It is believed that such a topology better embraces the complexity of shipping patterns than space- $\mathrm{L}$ where only direct inter-port stops are considered. The weight of nodes and links (or total traffic) equals the call frequency multiplied by vessel capacity measured in deadweight tonnage (DWT).

\subsubsection{Graph partitioning}

The main goal of this research is to confront the distribution and dynamics of maritime networks to the pre-established definition of port systems as units of references in the academic literature and beyond. Network analysis in general provides a wide variety of partitioning (or clustering) methods in order to reveal the main structure. Such methods have proved useful to test the relevance of borders of various kinds, such as cultural, political, and administrative borders, as in the case of mobile phone communications in Belgium for instance (Blondel et al., 2010).

Two main and complementary graph clustering methods are applied to the final network, namely single linkage analysis (SLA) and the Louvain algorithm. The single linkage analysis method is relatively straightforward, as it extracts the backbone of the network and its main hubs (if any), retaining for each node only its weightiest flow link in terms of total traffic (Nystuen and Dacey, 1961). Although the loss of information is huge by the deletion of many 
other links, SLA allows to delineate so-called "nodal regions" defined by one independent node and its subordinates.. Such a method already proved to be useful to analyse the structure of many networks of which maritime systems at various scales and overtime (see Wang and Wang, 2011; Ducruet and Notteboom, 2012 for early applications to the global container shipping network). Nodal regions are the reflection not only of hierarchical tendencies but also of barrier effects of various kinds, from geographic distance (cf. remoteness) to the influence of physical geography (coastlines, basins, closed seas, islands) and territorial factors. The latter effects include political instability, war, blockade, and often result in the isolation of certain nodal regions from the core(s) of the network (see Ducruet et al., 2018).

Contrary to SLA, the Louvain algorithm is applied on all linkages and therefore does not suffer a loss of information (Blondel et al., 2008). It consists in calculating intra- and inter-cluster variance based on the sole topology of the network (binary graph with 0 value without link and 1 value if any), resulting in a relatively small number of clusters. The Louvain method is thus less reliant on hierarchical tendencies as it focuses on the density of linkages to detect hidden groups of nodes. Other clustering methods were applied to maritime networks, such as modularity (Kaluza et al., 2010) but it is believed that comparing SLA and Louvain is sufficient to grasp the underlying systemic nature of port systems in the regions under consideration. The combination of the two methods was judged necessary to fully embrace how port systems can be delineated from a full network.

\subsubsection{Regional and temporal background}

Two case studies were selected to apply our methodology, namely North Europe and Northeast Asia. Those two regions have in common to comprise large gateways and large hubs - those being sometimes the same nodes, transhipping containers through sea-land services to/from the hinterland and through sea-sea services in the form of hub-and-spokes systems, notwithstanding shortsea shipping and coastal shipping flows that may bypass such large hubs to connect smaller nodes with each other. North Europe and Northeast Asia have also in common to bear significant physical barriers, such as the impossibility to transfer flows from South Korea to the Eurasian hinterland (cf. North Korea), the islandic nature of the British Isles, Japan, and Taiwan, and the relative separation of Scandinavia from the European 
mainland. Such barriers create both constraints and opportunities when it comes to connect the different parts of the two ensembles internally through shipping. Yet, the two regions are also very different in terms of their underlying territorial and economic functionality. North Europe is part of a wider commercial European Union where regional integration is high due to the low influence of national borders on intra-regional trade (note that our analysis only includes pre-Brexit data). In comparison, Northeast Asia is less integrated as it does not form a commercial union like the ASEAN in South Asia. Regional integration is an important factor in the establishment of coherent port systems as demonstrated by Lemarchand and Joly (2009) using port throughput as main variable. Northeast Asia was better seen by Rodrigue (1996) as a set of localized, subnational freight corridors rather than transnational ones due to such barrier effects and the fact that geographic distances are enormous compared with Europe.

In order to best compare the structure and evolution of port systems in the two regions under study, it was decided to run the analysis for three years with a ten-year interval, namely 1996, 2006, and 2016. Each selected year is a turning point for the maritime and ports sector, and especially for container shipping. The year 1996 marked the introduction of the first postPanamax container vessel which triggered consecutive waves of scale increases in ship size (Cullinane and Khanna, 2000; Ge et al., 2019). The mid 1990s also gave birth to the first strategic alliances among container carriers on the main east-west trade lanes (Notteboom et al., 2017). Combined with increased globalisation and liberalization of trade, these developments supported a growing centralization of shipping routes around large ports having sufficient cargo handling capacity (Rodrigue and Notteboom, 2010; Ducruet and Berli, 2019). The year 2006 was the last year of a boom period in the container shipping industry, partly as a result of the strong emergence of China as a major trade centre in the wake of its accession to the WTO in 2001. The year 2016, on the other hand, was one of the most difficult years for the shipping industry in recent history with a market characterised by extremely low freight rates, overcapacity and a strong focus of carriers on cost control through consolidation (i.e. a wave of M\&As), alliance formation and shipping network reconfigurations. It is our goal to study how port systems in those two regions adapted to such structural changes in the shipping industry, with the hypothesis that technological and operational changes may have either reinforced or altered the way ports connect each other through liner services. 
Before diving into the network analysis of the two regions, it is necessary to provide a more classic concentration analysis using the Gini coefficient. Yet our approach is original as it applies Gini to the traffic not only on ports but also on inter-port links (Table 3). Results show that traffic is highly concentrated in both regions. While Northeast Asia is more concentrated than North Europe, the region followed a decreasing trend over time. North Europe witnessed a de-concentration only in 2006.

Table 3: Vessel traffic concentration in Europe and Asia based on the Gini coefficient, 19962016

\subsection{Results}

\subsubsection{Hierarchical tendencies}

The application of SLA reveals that North Europe (NE) and Northeast Asia (NA) share interesting similarities in terms of port system configuration. Both regions have evolved from a monocentric to a polycentric structure, NE and NA being polarized in 1996 by Rotterdam and Hong Kong, respectively. These two main hubs are also the largest by their total vessel traffic (DWT) and they dominate most of other ports in a direct or indirect way. The rest of the period is marked by a reinforcement of the geographic specialization of hub dominance and by the growing importance of formerly secondary hubs. One exception is Le Havre, which remains a domestic hub centralizing flows uniquely within the French territory (Figure 2). Despite their bigger size and huge traffic growth, mainland Chinese ports also remained bound to national connectivity, emerging as domestic hubs in 2016 such as Yangshan (the offshore port complex of Shanghai), Beilun, Bayuquan, and Shanghai. For dominant hubs, we observe that Rotterdam's domination extended across the whole region in 1996 but gradually shrank due to a growing divide between Northeast and Northwest Europe. The initial specialization of Bremerhaven (Denmark-Sweden) and Hamburg (Baltic) on Scandinavia became more and more apparent overtime, as Rotterdam kept dominating mostly the British Isles, including the large gateway of Felixstowe. Yet, the analysis confirms for NE that these hubs form one large 
entity corresponding to the commonly used and cited Le Havre-Hamburg North European Range.

In Northeast Asia (Figure 3), the evolution of nodal regions followed a somewhat different path, shifting from a monocentric to a dual structure. Economic and logistics conditions fiercely impacted such a shift as seen with the growth of Busan (South Korea) from a secondary hub to a dominant hub and the decline of Japanese ports to such extent that they formed in 2006 and 2016 an isolated nodal region confined to the domestic level. One similarity however between north Europe and northeast Asia is the regional specialization of hubs. Busan's growth as a transhipment hub kept on polarizing adjacent secondary nodes in the Yellow Sea (i.e. North China, rest of Korea) and the East Sea (North Japan, Far East Russia), while Hong Kong's dominance became limited to the central and southern parts of mainland China. This reflects both the proactive strategy of South Korea to transform itself into an international logistics hub and the evolution of Hong Kong from a load centre to a financial hub doing less physical operations than supply chain management activities.

\subsubsection{Cluster density}

The application of the Louvain algorithm provides similarities and differences with SLA for the two regions under study. Antwerp and Le Havre belong to the same cluster in 1996 and 2016 together with numerous Scandinavian and British smaller ports (Figure 4). Bremerhaven stands apart in 1996 and 2006 and for the later year it includes a set of Norwegian ports as in the SLA. This is also the case of Hamburg for the three years under investigation. Rotterdam is part of the same cluster than Felixstowe in 1996, Antwerp in 2006, and Bremerhaven in 2016, making it difficult to establish a clear pattern. The geographic layout of clusters varies

greatly overtime so that the delineation of port systems remains difficult. Two similarities with SLA however are the inclusion of French ports in the same cluster than Le Havre at all years and the inclusion of certain British ports in the same cluster than Rotterdam but only in 1996 and 2006.

In Northeast Asia (Figure 5), the geographic logic of clusters is much more apparent than for North Europe. While Hong Kong stands apart in 1996, it is included in the same cluster than 
Shanghai and Ningbo in 1996, and shares the same cluster with most Taiwanese and mainland Chinese ports in 2016. The overall pattern in 2016 is thus highly similar to the one of SLA, with Hong Kong and Chinese ports being highly interdependent, Busan's influence extending across the Yellow and East seas, and Japanese main ports standing apart from the rest of the regional system. One exception with SLA is Osaka port belonging to the same cluster than Shanghai and Tianjin. Geographic proximity is also apparent with the cluster of northern Japanese small ports in 1996 and 2006, South Korean (e.g. Gwangyang, Busan) and Japanese south-western ports in 1996 and 2006. One special case is the cluster comprising main Japanese ports and Taiwanese ports in 1996 and 2006.

The discrepancy of cluster formation between Europe and Asia can be explained by the stronger importance of sea transport for Asian economies than for European ones. Asian port systems are more easily explained by geographic factors, notwithstanding certain exceptions, whereas for North Europe, the pattern is marked by greater volatility and complexity. In other words, carrier choices and shipping line logics that underlie port selection and network formation are more in line with geography in Asia than in Europe, where hinterland imperatives prevail.

\section{Discussion and conclusion}

The network analysis of maritime container flows helps us to rethink the way port systems are commonly understood by scholars and practitioners. One crucial result is that port systems are not fixed in space, due to the volatility of maritime networks. Therefore, their delineation should not be taken for granted and is not set in stone. However, existing port system studies tend to select samples of ports based on the assumption that those function in a formation network setting within political (national) or physical (seas, basins) boundaries. In our results, we observe a subtle mix between such proximities and other linkages, principally due to the distortions caused by hub-and-spokes systems. This implies that the network analysis approach allows to reveal interdependencies in port systems that go beyond the formation network level. For instance, many port systems studied per se in the literature such as the Bohai Rim, mainland China, Scandinavia, and the Baltic are in fact subsystems depending on an external transhipment hub, such as Busan, Hong Kong, and Hamburg, respectively. The functioning of 
these port systems can thus only be fully understood when adding chain and complex network attributes. Similarly, the British Isles as a port system would make no sense without considering the huge centralization power of Rotterdam on its external flows. Yet, large hubs taken altogether form transnational shipping corridors as already well depicted for decades in the literature, such as the Le Havre - Hamburg range that clearly appears in our results. National port systems are more subsystems away from the "core" of the network, such as Le Havre / France and Tokyo / Japan. For Japan, only the largest ports escape from the influence of Busan. For China, the centralization power of Busan in the North and Hong Kong in the South makes it difficult to speak of a comprehensive mainland Chinese port system, although the recent rise of Chinese domestic hubs seems to act as a counterforce against external polarization.

The findings of the presented analysis are a clear invitation to rethink the way port systems are usually considered at the local level. In a given region or range, the identification and inclusion of the dominant hub, should it be external to the region or part of it, seems to be a prerequisite of any analysis, to make the results closer to the reality of flows and to move beyond formation network aspects only. In highly centralized regions such as North Europe and Northeast Asia, but also others like the Caribbean, the Mediterranean and South Asia, such a shift of focus is necessary. Algeria's flows highly rely on the Maltese hub, the same applies to numerous Indian ports dependent on Colombo (Sri Lanka) and even U.S. ports served by the offshore hubs of the Caribbean. Although the offshore hub became included in port system evolutionary models (Notteboom and Rodrigue, 2005; Rodrigue and Notteboom, 2010), empirical studies tended to neglect its importance by continuing to analyse port systems from a pure inter-port competition point of view (i.e. formation network) based on national borders and coastline continuity. This is particularly true when the offshore hub stands geographically away from the studied port system. But from a maritime perspective, distance does not hold the same functionality than on earth, as vessels may be deployed with high frequencies between hubs and spokes separated by hundreds or thousands of kilometres.

One difficulty however of a maritime-based approach to port system configuration is practical, as scientists and practitioners are not always in possession of relational data capable of measuring and mapping the extent to which ports are linked to each other. As most port system studies rely on port throughput analysis, delineating with precision the relevant scale of 
analysis shall involve more efforts to discuss the definition of the chosen area and the nature of possible interdependencies among the nodes. Another difficulty is the probable mismatch between planning zones and maritime-based port systems, since the latter often extend beyond the authority of a given institution. This raises the question on how port systems could or should evolve if their configuration is left mainly in the hands of shipping lines. While traffic overconcentration in a few main ports might be against the EU objective of regional balance and distributional equity (Notteboom, 2009a), attempts to favour short-sea shipping and coastal shipping through, for instance, the EC Marco Polo initiatives fell short in shifting cargo flows from land to sea and from large to smaller ports.

\section{References}

Beresford, A., Pettit, S. (2009) A geographical perspective on port performance in the United Kingdom. In: Notteboom, T., Ducruet, C. and de Langen, P. (eds.) Ports in Proximity: Competition and Coordination among Adjacent Seaports, Transport and mobility series, Farnham: Ashgate, pp. 209-224.

Blondel V.D., Guillaume J.L., Lambiotte R., Lefebvre E. (2008) Fast unfolding of communities in large networks. Journal of Statistical Mechanics: Theory and Experiment, 2008(10): P10008.

Blondel V.D., Krings G.M., Thomas I. (2012) Regions and borders of mobile telephony in Belgium and around Brussels. Brussels Studies No. 42.

Brooks, M.R., Cullinane, K.P., Pallis, A.A. (2017) Revisiting port governance and port reform: A multi-country examination. Research in Transportation Business \& Management, 100(22): $1-10$.

Charlier, J.J. (1988) Structural change in the Belgian port system, 1980-1986. Maritime Policy \& Management, 15(4):315-326.

Comtois, C., Dong, J. (2007) Port competition in the Yangtze River delta. Asia Pacific Viewpoint, 48(3): 299-311.

De Langen, P.W., Van Meijeren, J., Tavasszy, L.A. (2012) Combining Models and Commodity Chain Research for Making Long-Term Projections of Port Throughput: an Application to the Hamburg-Le Havre Range. European Journal of Transport and Infrastructure Research, 12(3)

Ducruet C. (2020) The geography of maritime networks: a critical review. Journal of Transport Geography, 88: 102824. 
Ducruet C., Cuyala S., El Hosni A. (2018) Maritime networks as systems of cities: the longterm interdependencies between global shipping flows and urban development (1890-2010). Journal of Transport Geography, 66: 340-355.

Ducruet C., Rozenblat C., Zaidi F. (2010a) Ports in multi-level maritime networks: Evidence from the Atlantic (1996-2006)", Journal of Transport Geography, 18(4): 508-518.Ducruet C., Lee S.W., Ng A.K.Y. (2010b) Centrality and vulnerability in liner shipping networks: Revisiting the Northeast Asian port hierarchy. Maritime Policy and Management, 37(1): 1736.

Ducruet C., Notteboom T.E. (2012) The worldwide maritime network of container shipping: Spatial structure and regional dynamics. Global Networks, 12(3): 395-423.

Ducruet C., Notteboom T.E., De Langen P.W. (2009a) Revisiting inter-port relationships under the New Economic Geography research framework. Notteboom T.E., Ducruet C., De Langen P.W. (Eds.), Ports in Proximity: Competition and Cooperation among Adjacent Seaports, Aldershot, Ashgate, pp. 11-27.

Ducruet C., Roussin S., Jo J.C. (2009b) Going West? Spatial polarization of the North Korean port system. Journal of Transport Geography, 17(5): 357-368.

Ducruet C., Rozenblat C., Zaidi F. (2010a) Ports in multi-level maritime networks: Evidence from the Atlantic (1996-2006). Journal of Transport Geography, 18(4): 508-518.

Ducruet C., Wang L. (2018) China's global shipping connectivity: internal and external dynamics in the contemporary era (1890-2016). Chinese Geographical Science, 28(2): 2022016.

European Commission (2001) - Case No COMP/JV.56 - HUTCHISON / ECT (Rotterdam)

European Comission (2017) - Case M.8459 - TIL / PSA / PSA DGD (Antwerp)

Feng, L., Notteboom, T. (2013) Peripheral challenge by small and medium sized ports (SMPs) in multi-port gateway regions: the case study of northeast of China. Polish Maritime Research, 20: 55-66.

Freire Seoane M.J., Gonzalez-Laxe F., Montes C.P. (2013) Foreland determination for containership and general cargo ports in Europe (2007-2011). Journal of Transport Geography, 30: $56-67$.

Garcia-Alonso, L., Sanchez-Soriano, J. (2009) Port selection from a hinterland perspective. Maritime Economics \& Logistics, 11(3): 260-269.

Ge, J., Zhu, M., Sha, M., Notteboom, T., Shi, W., Wang, X. (2019) Towards 25,000 TEU vessels? A comparative economic analysis of ultra-large containership sizes under different market and operational conditions. Maritime Economics \& Logistics, 1-28. 
Gonzalez-Laxe F., Freire Seoane M.J., Montes C.P. (2012) Maritime degree, centrality and vulnerability: Port hierarchies and emerging areas in containerized transport (2008-2010). Journal of Transport Geography, 24: 33-44.

Gottmann J. (1961) Megalopolis: The Urbanized Northeastern Seaboard of the United States. New York: The Twentieth Century Fund.

Haezendonck, E., Coeck, C., Verbeke, A. (2000) The competitive position of seaports: Introduction of the value added concept. International Journal of Maritime Economics, 2(2): 107-118.

Hu Y., Zhu D. (2009) Empirical analysis of the worldwide maritime transportation network. Physica A, 388(10): 2061-2071.

Kaluza P., Kölzsch A., Gastner M.T., Blasius B. (2010) The complex network of global cargo ship movements. Journal of the Royal Society Interface, 7(48): 1093-1103.

Lam, J.S.L., Notteboom, T. (2014) The greening of ports: a comparison of port management tools used by leading ports in Asia and Europe. Transport Reviews, 34(2): 169-189.

Lam, J.S.L., Yap, W.Y. (2011) Dynamics of liner shipping network and port connectivity in supply chain systems: analysis on East Asia. Journal of Transport Geography, 19(6): 12721281.

Lemarchand A., Joly O. (2009) Regional integration and maritime range. In: Notteboom T.E., Ducruet C., De Langen P.W. (Eds.), Ports in Proximity: Competition and Coordination among Adjacent Seaports, Aldershot: Ashgate, pp. 87-99.

Li Z., Xu M., Shi Y. (2015) Centrality in global shipping network basing on worldwide shipping areas. Geojournal, 80(1): 47-60.

Liu, L., Wang, K.Y. and Yip, T.L. (2013) Development of a container port system in Pearl River Delta: path to multi-gateway ports. Journal of Transport Geography, 28: 30-38.

Liu C., Wang J., Zhang H., Yin M. (2018) Mapping the hierarchical structure of the global shipping network by weighted ego network analysis. International Journal of Shipping and Transport Logistics, 10(1): 63-86.

Low, J.M., Tang, L.C. (2012) Network effects in the East Asia container ports industry. Maritime Policy \& Management, 39(4): 369-386.

Marasco, A., Romano, A. (2018). Inter-port interactions in the Le Havre-Hamburg range: A scenario analysis using a nonautonomous Lotka Volterra model. Journal of Transport Geography, 69: 207-220. 
Mareï N., Ducruet C. (2015) The regionalization of maritime networks: Evidence from a comparative analysis of maritime basins. In: Ducruet C. (Ed.), Maritime Networks: Spatial Structures and Time Dynamics, Routledge Studies in Transport Analysis, pp. 330-350.

Meersman, H., Sys, C., Van de Voorde, E., Vanelslander, T. (2016) Road pricing and port hinterland competitiveness: An application to the Hamburg-Le Havre range. International Journal of Sustainable Transportation, 10(3): 170-179.

Merk, O. (2013) The competitiveness of global port-cities: synthesis report. OECD Regional Development Working Papers, no. 2013/13, OECD, Paris, 183 p.

Merkel, A. (2017) Spatial competition and complementarity in European port regions. Journal of Transport Geography, 61: 40-47.

NEA (2010) Ports and their connections within the TEN-T: Stakeholder Consultation Report, Reference R20100151/31126000/SNE/HBA, Zoetermeer, June 2010

Ng A.K.Y., Ducruet C. (2014) The changing tides of port geography (1950-2012). Progress in Human Geography, 38(6): 785-823.

Ng, A.K., Ducruet, C., Jacobs, W., Monios, J., Notteboom, T., Rodrigue, J.P., Slack, B., Tam, K.C., Wilmsmeier, G. (2014) Port geography at the crossroads with human geography: between flows and spaces. Journal of Transport Geography, 41: 84-96.

Notteboom, T. (1997) Concentration and load centre development in the European container port system. Journal of Transport Geography, 5(2): 99-115.

Notteboom T.E., Rodrigue J.P. (2005) Port regionalization: Towards a new phase in port development. Maritime Policy and Management, 32(3): 297-313.

Notteboom, T. (2006a) Traffic inequality in seaport systems revisited. Journal of Transport Geography, 14(2): 95-108.

Notteboom, T. (2006b) Notteboom, T.E., 2006. Container throughput dynamics in the East Asian container port system. Journal of International Logistics and Trade, 4(1): 31-52.

Notteboom, T. (2007). Spatial dynamics in the container load centers of the Le Havre-Hamburg range. Zeitschrift für Wirtschaftsgeographie, 51(1): 108-123.

Notteboom, T. (2009a). Economic analysis of the European seaport system. Report for European Sea ports Organisation (ESPO), ITMMA-University of Antwerp: Antwerp.

Notteboom, T. (2009b) Complementarity and substitutability among adjacent gateway ports. Environment and Planning A, 41(3): 743-762.

Notteboom, T. (2010). Concentration and the formation of multi-port gateway regions in the European container port system: an update. Journal of Transport Geography, 18(4): 567-583. 
Notteboom, T., de Langen, P.W. (2015). Container port competition in Europe. In: Handbook of Ocean Container Transport Logistics, Springer, pp. 75-95.

Notteboom, T., Parola, F., Satta, G., Pallis, A.A. (2017). The relationship between port choice and terminal involvement of alliance members in container shipping. Journal of Transport Geography, 64: 158-173.

Notteboom, T., Yang, Z. (2017). Port governance in China since 2004: Institutional layering and the growing impact of broader policies. Research in Transportation Business \& Management, 22: 184-200.

Nystuen J.D., Dacey M.F. (1961) A graph theory interpretation of nodal regions. Papers in Regional Science, 7(1), 29-42.

Plasschaert K., Derudder B., Dullaert W., Witlox F. (2011) Redefining the Hamburg - Le Havre range in maritime networks. Proceedings of the BIVE-GIBET Transport Research Day 2011, Zelzate, University Press, p. 240-244.

Rashed, Y., Meersman, H., Sys, C., Van de Voorde, E., Vanelslander, T. (2018) A combined approach to forecast container throughput demand: Scenarios for the Hamburg-Le Havre range of ports. Transportation Research Part A: Policy and Practice, 117: 127-141.

Rimmer P.J. (1967) The changing status of New Zealand seaports, 1853-1960. Annals of the Association of American Geographers, 57(1): 88-100.

Robinson R. (1968) Spatial Structuring of Port-Linked Flows: The Port of Vancouver, Canada, 1965. PhD Dissertation in Geography, University of British Columbia.

Robinson R. (1998) Asian hub/feeder nets: The dynamics of restructuring. Maritime Policy and Management, 25(1): 21-40.

Rodrigue J.P. (1996) Transportation corridors in Pacific Asian urban regions. Proceedings of the 7th World Conference on Transport Research, Sydney: Pergamon.

Shinohara, M. (2009). Port competition paradigms and Japanese port clusters. In: Notteboom, T., Ducruet, C. and de Langen, P. (eds.) Ports in Proximity: Competition and Coordination among Adjacent Seaports, Transport and mobility series, Farnham: Ashgate, pp. 263-272

Slack, B., Wang, J.J. (2002) The challenge of peripheral ports: an Asian perspective. GeoJournal, 56(2): 159-166.

Song, D.W., Yeo, K.T. (2004) A competitive analysis of Chinese container ports using the analytic hierarchy process. Maritime Economics \& Logistics, 6(1): 34-52. 
Soppé, M., Frémont, A. (2007) Northern European range: shipping line concentration and port hierarchy. In: Wang J, Olivier D, Notteboom T, Slack B (eds.), Ports, Cities, and Global Supply Chains, Ashgate, pp. 105-120

Thorez, P., Joly, O. (2006) Port Competition in the Northern Range from Le Havre to Hamburg. Promet-Traffic \& Transportation, 18(2):77-82.

Tran N.K., Haasis H.D. (2014) Empirical analysis of the container liner shipping network on the East-West corridor (1995-2011). Netnomics, 15(3): 121-153.

Trotta, M. (2000) Mediterranean and Northern Terminals: How is the Competition Developing?. International Journal of Maritime Economics, 2(4): 351-354.

Van Klink, H.A. (1995) Towards the borderless mainport Rotterdam: an analysis of functional, spatial and administrative dynamics in port systems, PhD Thesis, Erasmus University Rotterdam, No. 104

Veldman, S.J., Bückmann, E.H. (2003) A model on container port competition: an application for the West European container hub-ports. Maritime Economics \& Logistics, 5(1): 3-22.

Vigarié A. (1964) Les grands ports de commerce de la Seine au Rhin. Leur evolution devant l'industrialisation des arrière-pays. Paris: SABRI.

Wang C., Ducruet C. (2012) New port development and global city making: Emergence of the Shanghai-Yangshan multilayered gateway hub. Journal of Transport Geography, 25: 58-69.

Wang C., Ducruet C. (2013) Regional resilience and spatial cycles: Long-term evolution of the Chinese port system (221BC-2010AD). Tijdschrift voor Economische en Sociale Geografie, 104(5): 521-538.

Wang C., Wang J. (2011) Spatial pattern of the global shipping network and its hub-and-spoke system. Research in Transportation Economics, 32(1): 54-63.

Wang J.J., Ng A.K.Y. (2011) The geographical connectedness of Chinese seaports with foreland markets: A new trend? Tijdschrift voor Economische en Sociale Geografie, 102(2): $188-204$

Wang, J.J., Slack, B., 2000. The evolution of a regional container port system: the Pearl River Delta. Journal of Transport Geography, 8(4): 263-275.

Wang, L., Notteboom, T., Lau, Y.Y., Ng, A.K. (2017). Functional differentiation and sustainability: A new stage of development in the Chinese container port system. Sustainability, 9(3): 328.

Wang L.H., Lin Y.S., Ducruet C. (2019) Study on the changes of ports' connection across the Taiwan Strait in the global maritime network. Acta Geographica Sinica, 73(12): 2282-2296. 
Wang Y., Cullinane K. (2008) Measuring container port accessibility: An application of the Principal Eigenvector Method (PEM). Maritime Economics and Logistics, 10: 75-89.

Wang Y., Cullinane K. (2014) Traffic consolidation in East Asian container ports: A network flow analysis. Transportation Research Part A, 61: 152-163.

Wiegmans, B., Dekker, S. (2016) Benchmarking deep-sea port performance in the HamburgLe Havre range. Benchmarking: An International Journal.

Unicredit (2010) Maritime Trend Barometer, Hamburg, February 2010

Xu M., Li Z., Shi Y., Zhang X., Jiang S. (2015) Evolution of regional inequality in the global shipping network. Journal of Transport Geography, 44: 1-12.

Yanbing, Y., Zhongzhen, Y., Zan, Y., Zhi, Z. (2005) Evaluation of competition ability and market share for container port. Proceedings of the Eastern Asia Society for Transportation Studies, 5: 2483-2493 


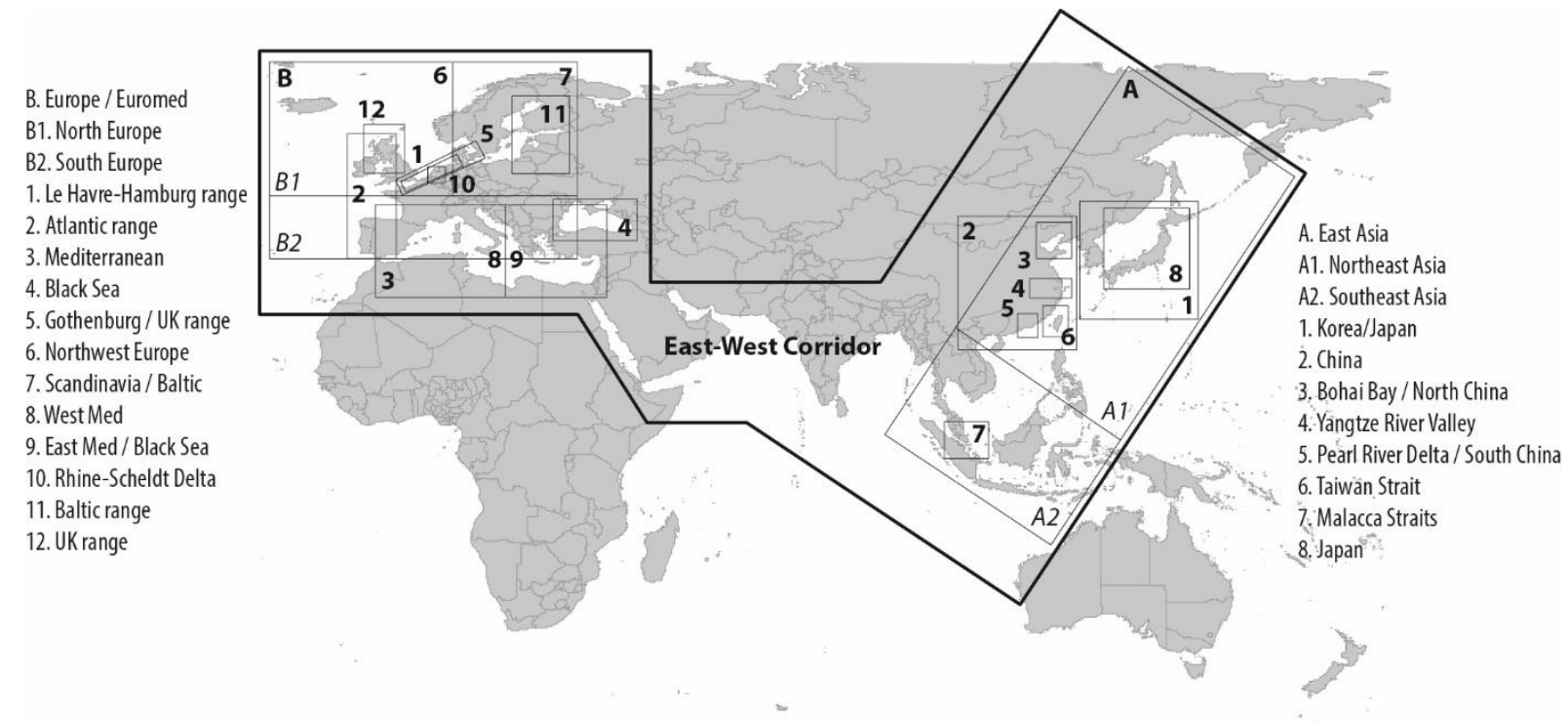

Figure 1: Cartography of recurrent maritime ranges 


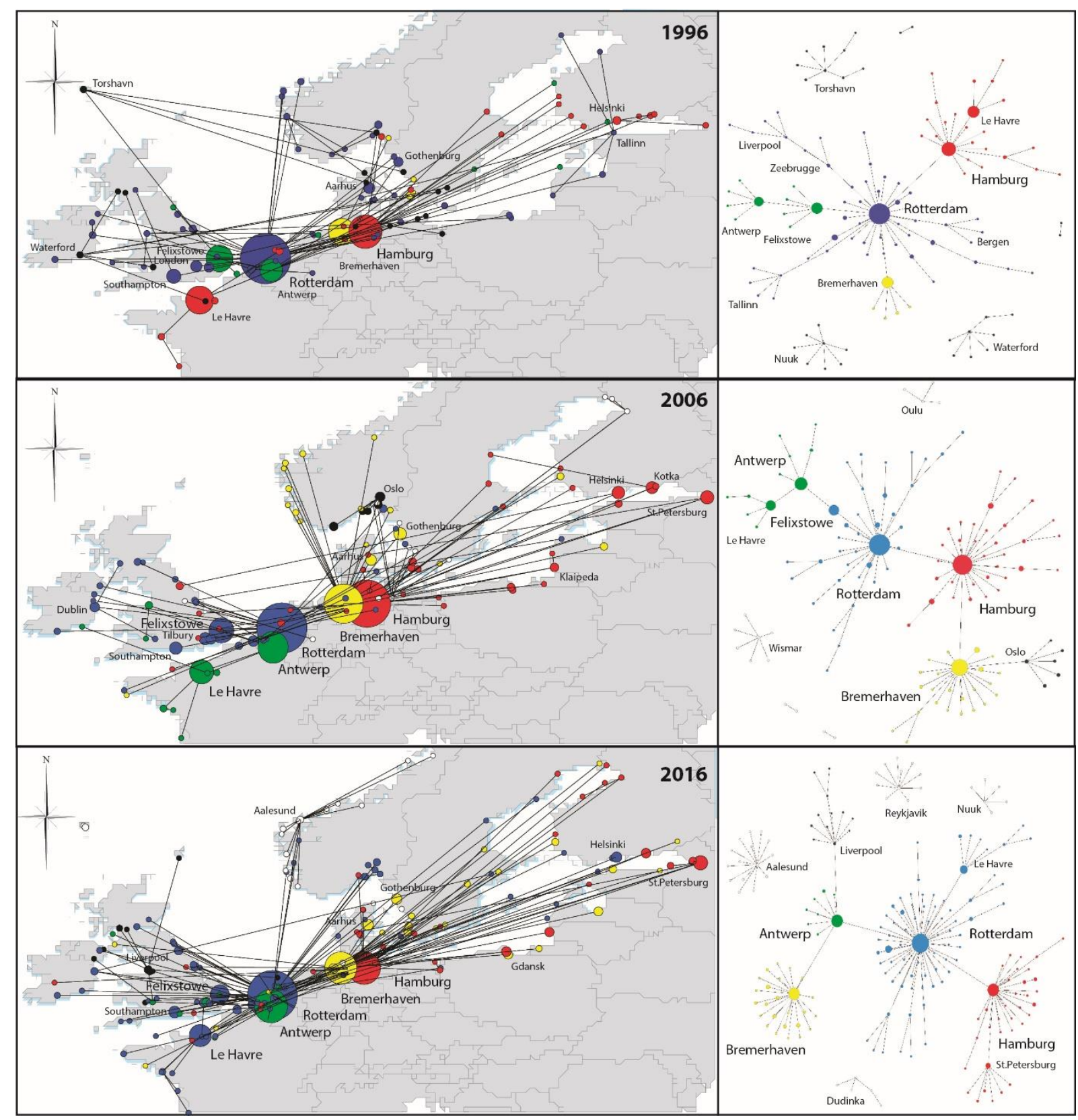

Figure 2: Single linkage analysis of North European container flows, 1996-2016 


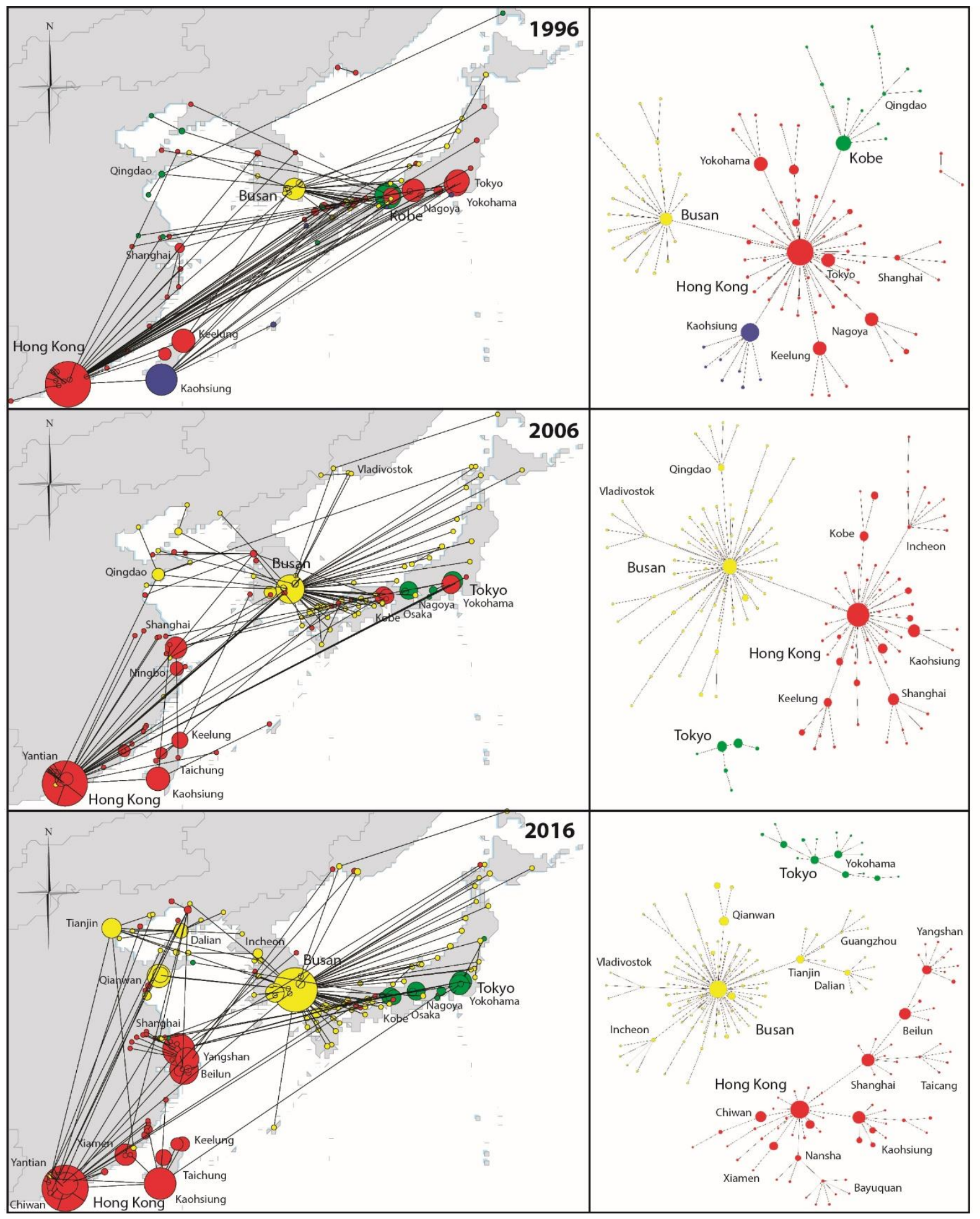

Figure 3: Single linkage analysis of Northeast Asian container flows, 1996-2016 


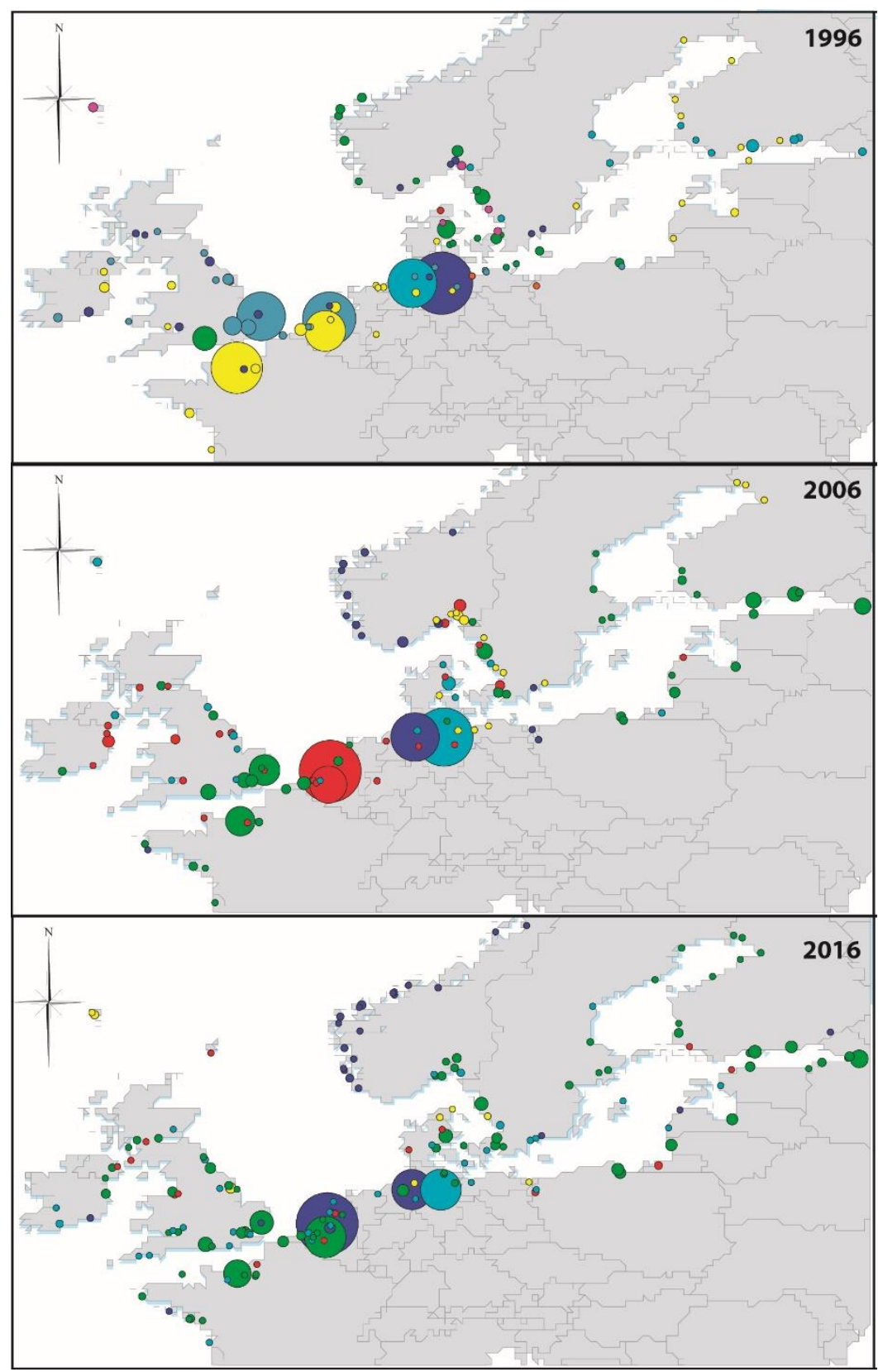

Figure 4: Cluster identification among North European container ports, 1996-2016 


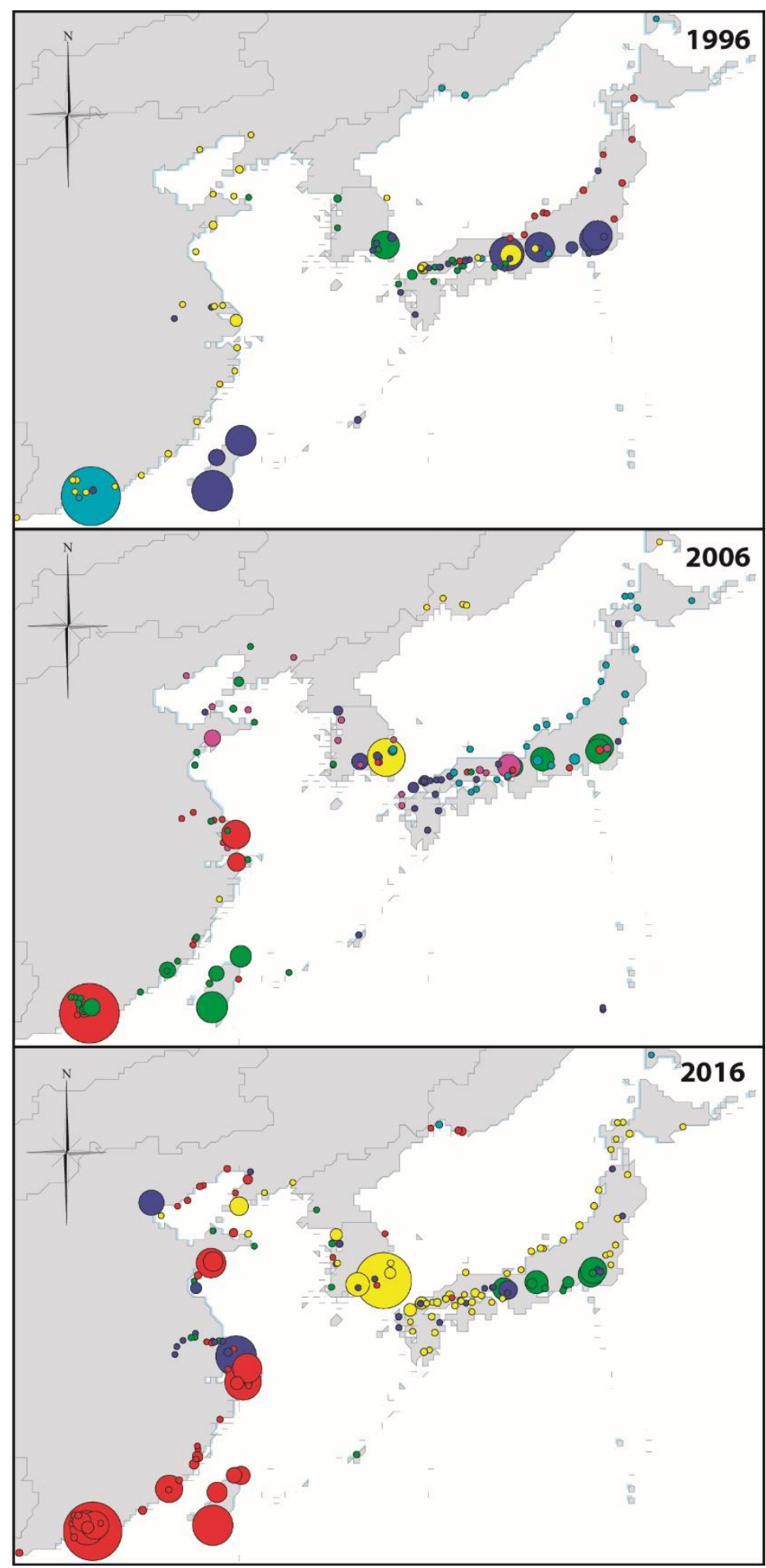

Figure 5: Cluster identification among Northeast Asian container ports, 1996-2016 


\begin{tabular}{|c|c|c|c|c|c|c|c|c|c|c|c|c|c|c|c|c|c|c|c|c|c|}
\hline & \multicolumn{3}{|c|}{ Cargo } & \multicolumn{3}{|c|}{ Unit } & \multirow[t]{2}{*}{ Period } & \multicolumn{8}{|c|}{ Main methodological focus } & \multicolumn{3}{|c|}{ Interdependencies } & \multicolumn{3}{|c|}{ Port system (no. of ports considered) } \\
\hline & 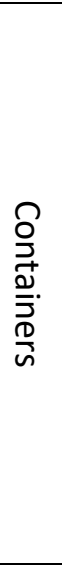 & $\underset{\text { 号 }}{\stackrel{\text { त }}{\pi}}$ & 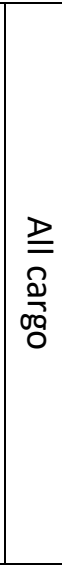 & 耍 & $\stackrel{0}{\circ}$ & 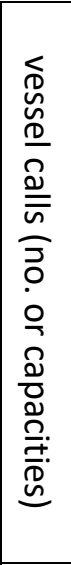 & & 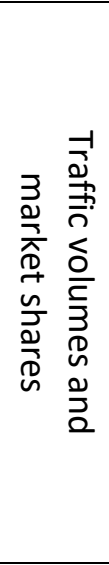 & 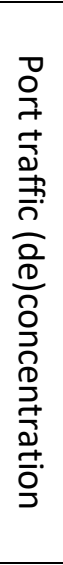 & 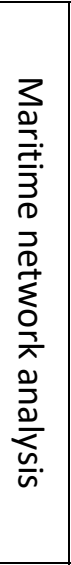 & 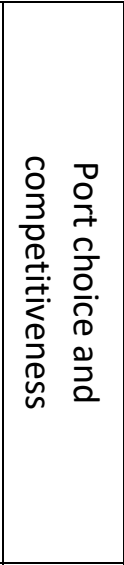 & 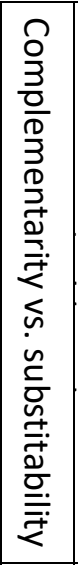 & 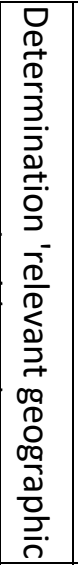 & 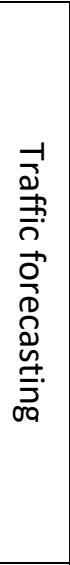 & 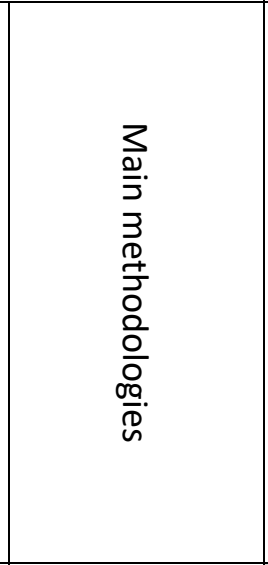 & 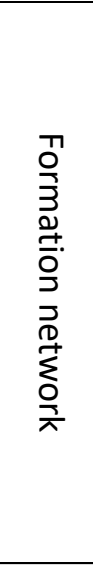 & 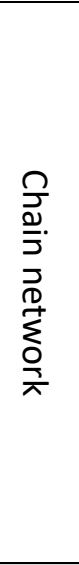 & 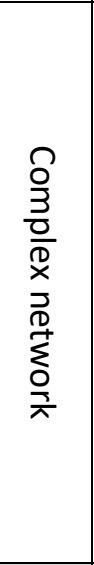 & 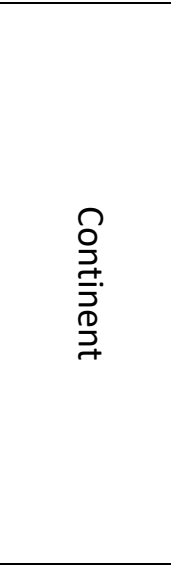 & 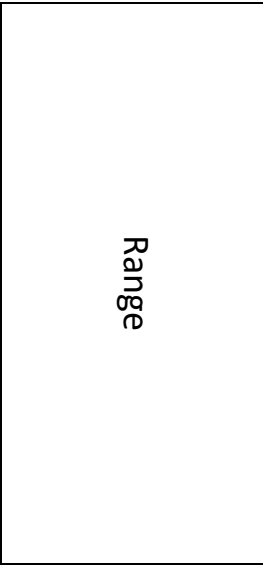 & 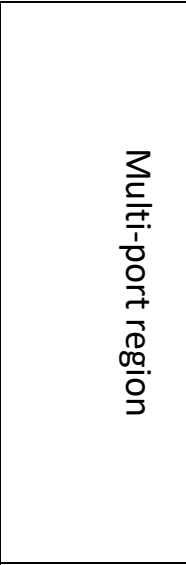 \\
\hline $\begin{array}{l}\text { Notteboom } \\
\text { (1997) }\end{array}$ & $x$ & & & $\mathrm{x}$ & & & $\begin{array}{l}1980- \\
1994\end{array}$ & $x$ & $x$ & & & & & & $\begin{array}{l}\text { Gini coefficient } \\
\text { Net shift analysis }\end{array}$ & $x$ & & & Europe (36) & \begin{tabular}{|l|} 
Hamburg-Le Havre \\
range (11) \\
Atlantic range (9) \\
Mediterranean - \\
Europe (16) \\
\end{tabular} & nihil \\
\hline $\begin{array}{l}\text { Charlier } \\
\text { (1998) }\end{array}$ & $x$ & & & $\mathrm{x}$ & & & $\begin{array}{c}1980- \\
1986 \\
\end{array}$ & $x$ & & & & & & & & $\mathrm{x}$ & & & & & Benelux \\
\hline Trotta (2000) & $\mathrm{x}$ & & & $x$ & & & $\begin{array}{l}1997- \\
2000\end{array}$ & $x$ & & & $x$ & & & & & $x$ & & & Europe & \begin{tabular}{|l} 
Northern ports (F, \\
NL, BE, DE and PL) \\
vs. Southern ports \\
(ESP, F, I, SL, CRO, \\
HE) \\
\end{tabular} & \\
\hline $\begin{array}{l}\text { Haezendonck } \\
\text { et al (2000) }\end{array}$ & $\mathrm{x}$ & & $x$ & $\mathrm{x}$ & $\mathrm{x}$ & & $\begin{array}{l}1980- \\
1998\end{array}$ & $x$ & & & $x$ & & & & \begin{tabular}{|l|} 
Statistical analysis \\
of survey on \\
competitive \\
advantage
\end{tabular} & $\mathrm{x}$ & & & & $\begin{array}{l}\text { Antwerp within } \\
\text { Hamburg-Le Havre } \\
\text { range }\end{array}$ & \\
\hline $\begin{array}{l}\text { European } \\
\text { Commission } \\
\text { (2001) - Case } \\
\text { No } \\
\text { COMP/JV.56 }\end{array}$ & $x$ & & & $\mathrm{x}$ & & & & $x$ & & & & & $\mathrm{x}$ & & & $x$ & & & & \begin{tabular}{|l|} 
For hinterland: \\
RGM comprises \\
continental \\
Northern Europe \\
For transhipment:
\end{tabular} & \\
\hline
\end{tabular}




\begin{tabular}{|c|c|c|c|c|c|c|c|c|c|c|c|c|c|c|c|c|c|}
\hline $\begin{array}{l}\text { - HUTCHISON } \\
\text { / ECT } \\
\text { (Rotterdam) }\end{array}$ & & & & & & & & & & & & & & & & $\begin{array}{l}\text { RGM comprises } \\
\text { the Gothenburg-Le } \\
\text { Havre range (incl. } \\
\text { UK) }\end{array}$ & \\
\hline $\begin{array}{l}\text { Veldman and } \\
\text { Bückmann } \\
\text { (2003) }\end{array}$ & $x$ & & $x$ & & & & & & & $x$ & & $\begin{array}{l}\text { Port Competition } \\
\text { Logit Model (port } \\
\text { choice linked to } \\
\text { hinterland } \\
\text { regions) } \\
\end{array}$ & $x$ & & & $\begin{array}{l}\text { Antwerp-Hamburg } \\
\text { range (4) }\end{array}$ & \\
\hline $\begin{array}{l}\text { Notteboom } \\
\text { (2006a) }\end{array}$ & $x$ & & $x$ & & & $\begin{array}{l}1975- \\
2003\end{array}$ & $x$ & $x$ & & & & $\begin{array}{l}\text { Gini } \\
\text { Decomposition }\end{array}$ & $x$ & & Europe (47) & $\begin{array}{l}\text { Hamburg-Le Havre } \\
\text { range (14) } \\
\text { Atlantic range (9) } \\
\text { Mediterranean - } \\
\text { Europe (20) } \\
\text { UK range (4) }\end{array}$ & \\
\hline $\begin{array}{l}\text { Thorez and } \\
\text { Olivier } \\
\text { (2006) }\end{array}$ & $x$ & $x$ & $x$ & $x$ & & $\begin{array}{l}1995- \\
2004\end{array}$ & $x$ & & & $x$ & & $\begin{array}{l}\text { Qualitative } \\
\text { discussion of port } \\
\text { competitiveness } \\
\text { factors }\end{array}$ & $x$ & & & $\begin{array}{l}\text { Hamburg-Le Havre } \\
\text { range }\end{array}$ & \\
\hline $\begin{array}{l}\text { Soppé and } \\
\text { Frémont } \\
\text { (2007) }\end{array}$ & $x$ & & & & $x$ & & $x$ & $x$ & & $x$ & $x$ & & $x$ & $x$ & & $\begin{array}{l}\text { North European } \\
\text { range }\end{array}$ & \\
\hline $\begin{array}{l}\text { Notteboom } \\
(2007)\end{array}$ & $x$ & & $x$ & & $x$ & $\begin{array}{l}1975- \\
2006\end{array}$ & $x$ & $x$ & $x$ & & & $\begin{array}{l}\text { Gini coefficient } \\
\text { Net shift analysis } \\
\text { Distribution of } \\
\text { vessel calls }\end{array}$ & $x$ & & & $\begin{array}{l}\text { Hamburg-Le Havre } \\
\text { range }\end{array}$ & $\begin{array}{l}\text { sub-division of } \\
\text { range per coun } \\
\text { (BE; DE; F and } ~ \\
\text { sub-division } \\
\text { between upstre } \\
\text { vs. coastal port }\end{array}$ \\
\hline $\begin{array}{l}\text { Notteboom } \\
\text { (2009b) }\end{array}$ & $x$ & & $x$ & & $x$ & & $x$ & & $x$ & $x$ & $x$ & $\begin{array}{l}\text { Analysis vessel } \\
\text { calls }+ \text { hinterland } \\
\text { traffic + measures } \\
\text { for level of } \\
\text { substitutability } \\
\text { between ports }\end{array}$ & $x$ & & & & $\begin{array}{l}\text { Rhine-Scheldt D } \\
\text { (here coined as } \\
\text { "ZARA ports") }\end{array}$ \\
\hline
\end{tabular}




\begin{tabular}{|c|c|c|c|c|c|c|c|c|c|c|c|c|c|c|c|c|}
\hline $\begin{array}{l}\text { Beresford } \\
\text { and Pettitt } \\
\text { (2009) }\end{array}$ & $x$ & $\mathrm{x}$ & $\mathrm{x}$ & $\mathrm{x}$ & & $\begin{array}{l}1999- \\
2007\end{array}$ & $x$ & & $x$ & & $x$ & & & & United Kingdom & \begin{tabular}{|l} 
Tyne Tees (2); \\
Humber (5); Eas \\
Anglia (3); Soutl \\
East (4); South \\
Coast (2); Bristo \\
Channel (6); \\
Northwest/Mer \\
(4)
\end{tabular} \\
\hline $\begin{array}{l}\text { Garcia- } \\
\text { Alonso \& } \\
\text { Sanchez- } \\
\text { Soriano } \\
\text { (2009) }\end{array}$ & $\mathrm{x}$ & & & & & & & & $x$ & $\begin{array}{l}\text { Port choice from } \\
\text { hinterland } \\
\text { perspective using } \\
\text { discrete choice } \\
\text { model }\end{array}$ & $\mathrm{x}$ & & & & $\begin{array}{l}\text { Spain (with focus } \\
\text { on Bilbao, } \\
\text { Algeciras, Valencia } \\
\text { and Barcelona) }\end{array}$ & \\
\hline $\begin{array}{l}\text { Ducruet et } \\
\text { al. (2010a) }\end{array}$ & $x$ & & & & $x$ & $\begin{array}{l}1996- \\
2006\end{array}$ & & $\mathrm{x}$ & & Bisecting K-means & & $x$ & $x$ & Atlantic & $\begin{array}{l}\text { functional Le } \\
\text { Havre - Hamburg } \\
\text { range }\end{array}$ & \\
\hline $\begin{array}{l}\text { Unicredit } \\
\text { (2010) - } \\
\text { Maritime } \\
\text { Trend } \\
\text { Barometer }\end{array}$ & & $\mathrm{x}$ & & & & & & & $x$ & $\begin{array}{l}\text { Ranking of ports } \\
\text { based on logistics } \\
\text { performance }\end{array}$ & $x$ & & & & $\begin{array}{l}\text { Selection of NW- } \\
\text { European ports } \\
\text { (Amsterdam, } \\
\text { Felixstowe, } \\
\text { Wilhelmshaven, } \\
\text { Zeebrugge, } \\
\text { Bremerhaven, } \\
\text { Antwerpen, } \\
\text { Rotterdam, } \\
\text { Hamburg) }\end{array}$ & \\
\hline NEA (2010) & $x$ & $x$ & $x$ & $\mathrm{x}$ & & $\begin{array}{c}2005- \\
\text { forecasts } \\
\text { till } 2030\end{array}$ & $x$ & & & $\begin{array}{l}\text { Modelling the } \\
\text { selection of core } \\
\text { ports in TEN-T EU }\end{array}$ & $x$ & & $x$ & & $\begin{array}{l}\text { TEN-Connect port } \\
\text { grouping: } \\
\text { Hamburg-Le Havre; } \\
\text { GB/Ireland; } \\
\text { Nordic/Baltic; } \\
\text { Atlantic Arc; West- } \\
\text { Med; East Med and } \\
\text { Black Sea }\end{array}$ & \\
\hline
\end{tabular}




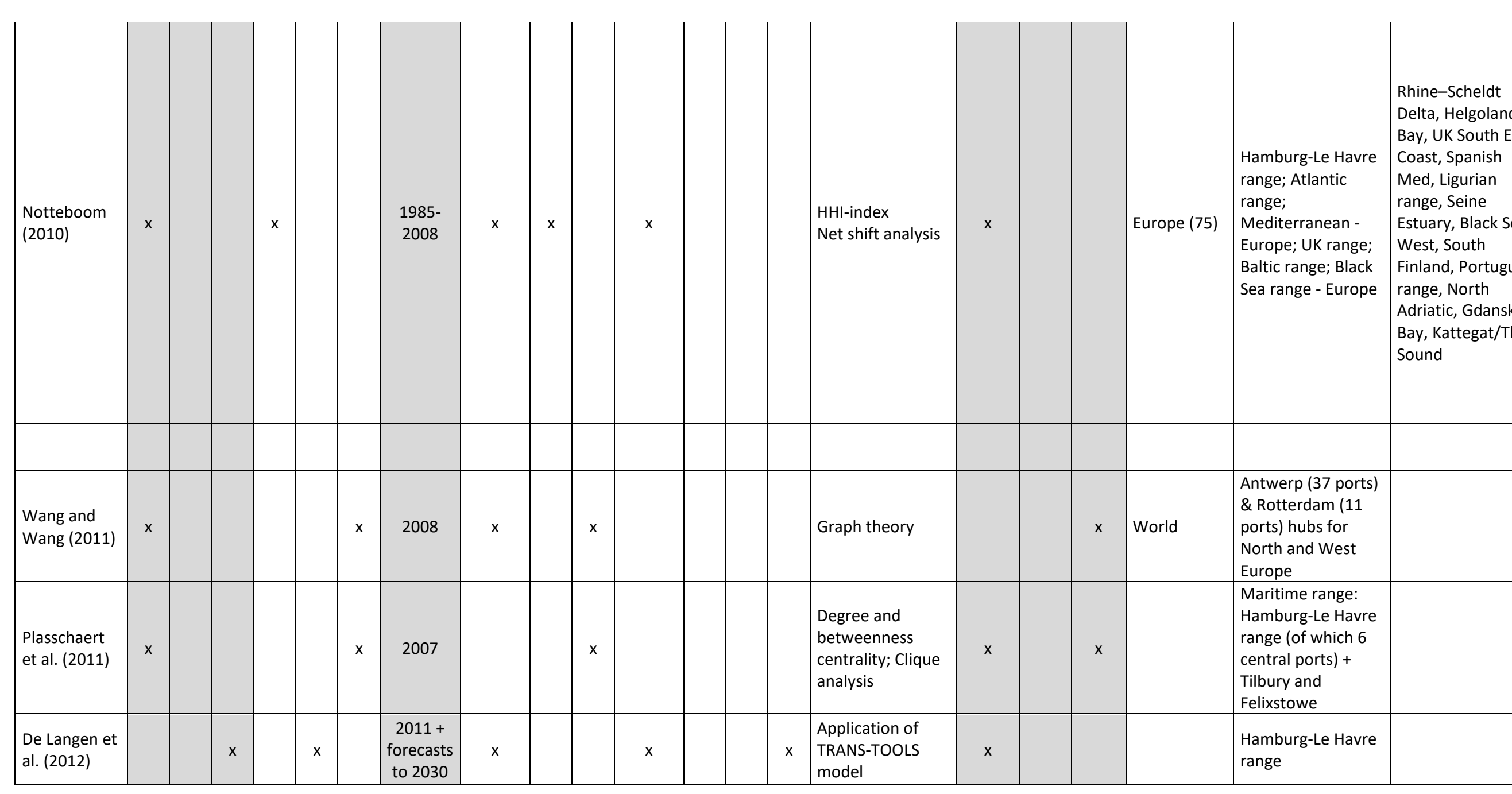




\begin{tabular}{|c|c|c|c|c|c|c|c|c|c|c|c|c|c|c|c|c|c|c|}
\hline $\begin{array}{l}\text { Ducruet and } \\
\text { Notteboom } \\
\text { (2012) }\end{array}$ & $x$ & & & & $x$ & $\begin{array}{l}1996- \\
2006\end{array}$ & & $x$ & $x$ & & & $\begin{array}{l}\text { Single linkage } \\
\text { analysis }\end{array}$ & $x$ & $x$ & $x$ & $\begin{array}{l}\text { Northwest } \\
\text { Europe as } \\
\text { independent } \\
\text { nodal region } \\
+ \\
\text { transatlantic } \\
\text { tiny links } \\
\end{array}$ & & \\
\hline $\begin{array}{l}\text { Freire } \\
\text { Seoane et al. } \\
\text { (2013) }\end{array}$ & $x$ & $x$ & & & $x$ & $\begin{array}{l}2007- \\
2011\end{array}$ & & & $x$ & & & $\begin{array}{l}\text { Complex } \\
\text { networks }\end{array}$ & & & $x$ & World & $\begin{array}{l}\text { North European } \\
\text { core }\end{array}$ & \\
\hline $\begin{array}{l}\text { Wiegmans \& } \\
\text { Dekker } \\
\text { (2014) }\end{array}$ & $x$ & $x$ & $x$ & $x$ & & & $x$ & & & & & $\begin{array}{l}\text { Data } \\
\text { Envelopment } \\
\text { Analysis } \\
\end{array}$ & $x$ & & & & $\begin{array}{l}\text { Hamburg-Le Havre } \\
\text { range (11) }\end{array}$ & \\
\hline $\begin{array}{l}\text { Notteboom } \\
\text { \& De Langen } \\
\text { (2015) }\end{array}$ & $x$ & & $x$ & & & $\begin{array}{l}1985- \\
2012\end{array}$ & $x$ & & & & $x$ & & $x$ & & & Europe (75) & $\begin{array}{l}\text { same as } \\
\text { Notteboom (2010) }\end{array}$ & $\begin{array}{l}\text { same as } \\
\text { Notteboom (20 }\end{array}$ \\
\hline $\begin{array}{l}\text { Li et al. } \\
(2015)\end{array}$ & $x$ & & & & $x$ & $\begin{array}{l}2001- \\
2012\end{array}$ & $x$ & & $x$ & & & Graph theory & & & $x$ & World & Europe, Baltic & \\
\hline $\begin{array}{l}\text { Xu et al. } \\
\text { (2015) }\end{array}$ & $x$ & & & & $x$ & $\begin{array}{l}2001- \\
2012\end{array}$ & $x$ & & $x$ & & & Graph theory & & & $x$ & $\begin{array}{l}\text { World - NW } \\
\text { europe as } \\
\text { subregion }\end{array}$ & & \\
\hline \begin{tabular}{l|} 
Tran and \\
Haasis (2015) \\
\end{tabular} & $x$ & & & & $x$ & $\begin{array}{l}1995- \\
2011\end{array}$ & $x$ & & $x$ & & & & & $x$ & & $\begin{array}{l}\text { East-West } \\
\text { corridor }\end{array}$ & Northern Europe & \\
\hline $\begin{array}{l}\text { Meersman et } \\
\text { al. (2016) }\end{array}$ & $x$ & & $x$ & & & & & & & $x$ & & $\begin{array}{l}\text { Cost model for } \\
\text { hinterland } \\
\text { trucking with } \\
\text { consideration of } \\
\text { road pricing } \\
\text { schemes }\end{array}$ & $x$ & & & & $\begin{array}{l}\text { Hamburg-Le Havre } \\
\text { range }\end{array}$ & \\
\hline \begin{tabular}{l|} 
European \\
Comission \\
(2017) - Case \\
M.8459 - TIL \\
/ PSA / PSA \\
DGD \\
(Antwerp)
\end{tabular} & $x$ & & $x$ & & & & $x$ & & & & $x$ & & $x$ & & & & $\begin{array}{l}\text { For hinterland: } \\
\text { RGM at least } \\
\text { comprises the } \\
\text { ports of Antwerp } \\
\text { and Rotterdam and } \\
\text { probably the entire } \\
\text { Hamburg-Le Havre }\end{array}$ & \\
\hline
\end{tabular}




\begin{tabular}{|c|c|c|c|c|c|c|c|c|c|c|c|c|c|c|c|c|}
\hline & & & & & & & & & & & & & & & $\begin{array}{l}\text { range. } \\
\text { For transhipment: } \\
\text { RGM comprises at } \\
\text { the very least the } \\
\text { Hamburg-Le Havre } \\
\text { range. }\end{array}$ & \\
\hline $\begin{array}{l}\text { Kleman } \\
\text { (2017) }\end{array}$ & & $x$ & & $x$ & $\begin{array}{l}1648- \\
2000\end{array}$ & $x$ & & $x$ & & & $\begin{array}{l}\text { Long-term trends } \\
\text { in inter-port } \\
\text { competition }\end{array}$ & $\mathrm{x}$ & & & $\begin{array}{l}\text { Hamburg-Le Havre } \\
\text { range }\end{array}$ & \\
\hline $\begin{array}{l}\text { Merkel } \\
\text { (2017) }\end{array}$ & $x$ & & $x$ & & $\begin{array}{l}2000- \\
2014\end{array}$ & $x$ & & & $x$ & & $\begin{array}{l}\text { Spatial } \\
\text { dependence } \\
\text { model to } \\
\text { measure } \\
\text { complementarity/ } \\
\text { competition } \\
\text { between ports in } \\
\text { the same region }\end{array}$ & $x$ & & Europe (92) & $\begin{array}{l}\text { Hamburg-Le Havre } \\
\text { region (17): } \\
\text { characterized } \\
\text { mostly by } \\
\text { competition } \\
\text { Mediterranean } \\
\text { region (27): } \\
\text { complementary } \\
\text { with regard to } \\
\text { demand. } \\
\text { Atlantic region (10) } \\
\text { Baltic/Scandinavian } \\
\text { region (23) } \\
\text { UK region (15) } \\
\end{array}$ & Country level \\
\hline $\begin{array}{l}\text { Rashed et al } \\
\text { (2018) }\end{array}$ & $x$ & & $x$ & & $\begin{array}{c}1995- \\
2007 \\
+ \\
\text { forecasts }\end{array}$ & $x$ & & & & $x$ & $\begin{array}{l}\text { Demand } \\
\text { forecasting model } \\
\text { for container } \\
\text { throughput (incl. } \\
\text { elasticity to trade } \\
\text { indices) } \\
\end{array}$ & $x$ & & & $\begin{array}{l}\text { Hamburg-Le Havre } \\
\text { range }\end{array}$ & \\
\hline $\begin{array}{l}\text { Liu et al. } \\
\text { (2018) }\end{array}$ & $x$ & & & & 2014 & & $x$ & & & & $\begin{array}{l}\text { Complex } \\
\text { networks } \\
\end{array}$ & & $x$ & World & Europe & \\
\hline & & & & & & & & & & & & & & & & \\
\hline $\begin{array}{l}\text { Marasco and } \\
\text { Romano } \\
(2018)\end{array}$ & $\mathrm{x}$ & & $x$ & & $\begin{array}{c}1990- \\
2014+ \\
\text { forecasts } \\
\text { till } 2022\end{array}$ & $x$ & & $x$ & $x$ & $x$ & $\begin{array}{l}\text { Scenario analysis } \\
\text { based on Lotka } \\
\text { Volterra model }\end{array}$ & $x$ & & & $\begin{array}{l}\text { Hamburg-Le Havre } \\
\text { range (6) }\end{array}$ & $\begin{array}{l}\text { Benelux ports: } \\
\text { switching to } \\
\text { 'mutualism' } \\
\text { German ports: } \\
\text { expected to }\end{array}$ \\
\hline
\end{tabular}




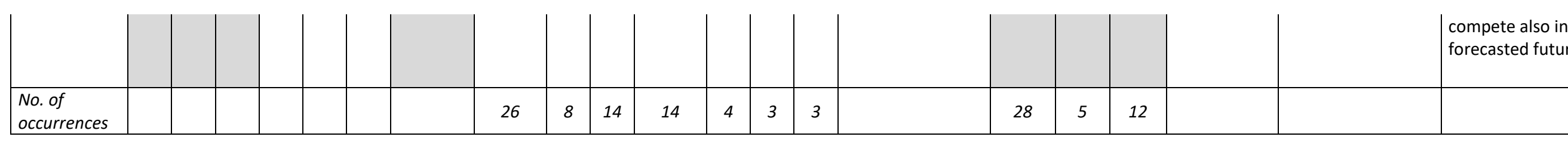

Table 1: Typology of selected works on port systems in North Europe

Source: own elaboration 


\begin{tabular}{|c|c|c|c|c|c|c|c|c|c|c|c|c|c|c|c|c|c|c|c|c|c|}
\hline & \multicolumn{3}{|c|}{ Cargo } & \multicolumn{3}{|c|}{ Unit } & \multirow[t]{2}{*}{ Period } & \multicolumn{8}{|c|}{ Main methodological focus } & \multicolumn{3}{|c|}{ Interdependencies } & \multicolumn{3}{|c|}{ Port system (no. of ports considered) } \\
\hline & $\begin{array}{l}\frac{\delta}{2} \\
\frac{d}{0} \\
\frac{0}{\overline{0}} \\
\frac{0}{n}\end{array}$ & 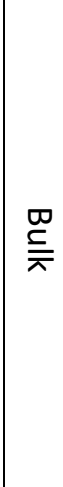 & 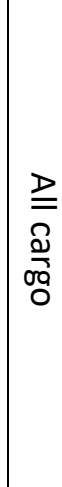 & 自 & के & 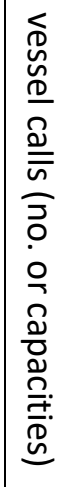 & & 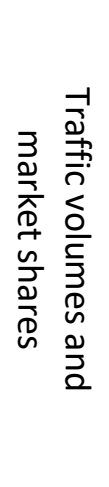 & 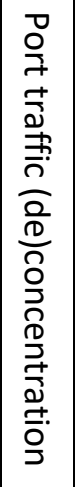 & 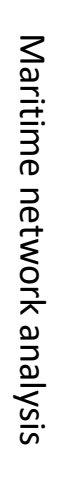 & 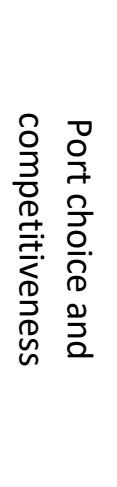 & 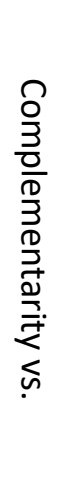 & 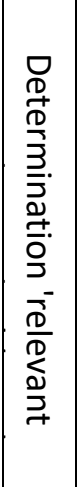 & 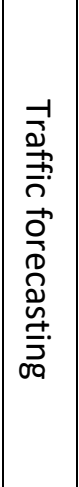 & 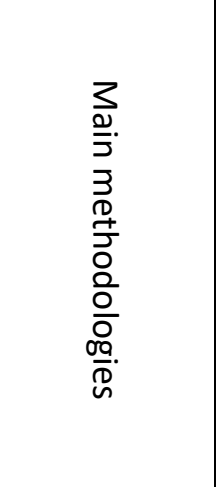 & 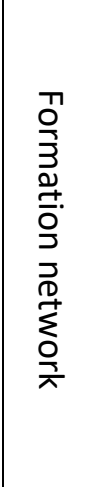 & 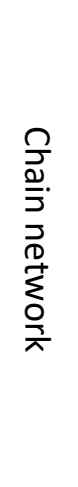 & 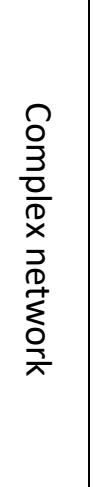 & 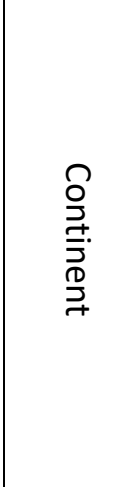 & 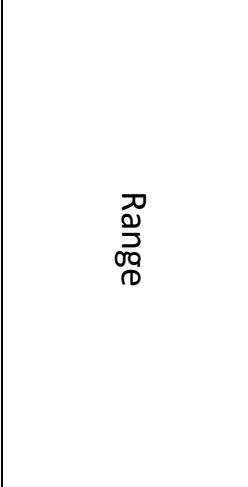 & 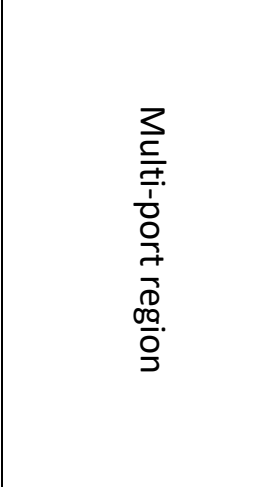 \\
\hline $\begin{array}{l}\text { Wang and } \\
\text { slack (2000) }\end{array}$ & & & & & & & & & & & & & & & & $x$ & & & & & Pearl-River Delta \\
\hline $\begin{array}{l}\text { Slack and } \\
\text { Wang } \\
\text { (2002) } \\
\end{array}$ & $x$ & & & $x$ & & & $\begin{array}{l}1996- \\
1999\end{array}$ & $x$ & $x$ & & $x$ & & & & $\begin{array}{l}\text { Challenge of } \\
\text { the periphery }\end{array}$ & $x$ & & & & & $\begin{array}{l}\text { Pearl-River Delta; } \\
\text { Yangtze River Delta; } \\
\text { Malacca Straits }\end{array}$ \\
\hline $\begin{array}{l}\text { Song and } \\
\text { Yeo (2004) }\end{array}$ & $\mathrm{x}$ & & & $\mathrm{x}$ & & & $\begin{array}{l}2001- \\
2002\end{array}$ & $x$ & & & $x$ & & & & $\begin{array}{l}\text { Competitive } \\
\text { analysis } \\
\text { using AHP }\end{array}$ & & & & China (8) & & \\
\hline $\begin{array}{l}\text { Yanbing et } \\
\text { al. (2005) }\end{array}$ & $\mathrm{x}$ & & & $\mathrm{x}$ & & & & $x$ & & & $x$ & & & & $\begin{array}{l}\text { Model for port } \\
\text { competition } \\
\text { ability } \\
\text { combined with } \\
\text { AHP }\end{array}$ & & & & & $\begin{array}{l}\text { Bohai Bay - China } \\
\text { (5) }\end{array}$ & \\
\hline
\end{tabular}




\begin{tabular}{|c|c|c|c|c|c|c|c|c|c|c|c|c|c|c|c|c|}
\hline $\begin{array}{l}\text { Notteboom } \\
\text { (2006b) }\end{array}$ & $x$ & & $x$ & & $\begin{array}{l}1980- \\
2004\end{array}$ & $x$ & $x$ & & & & $\begin{array}{l}\text { Gini } \\
\text { Decomposition }\end{array}$ & $x$ & & $\begin{array}{l}\text { East-Asia } \\
(27)\end{array}$ & $\begin{array}{l}\text { Bohai Bay (3) } \\
\text { Yangtze River } \\
\text { Delta (2) } \\
\text { Taiwan (3) } \\
\text { Trans-Taiwan (2) } \\
\text { Pearl River Delta } \\
\text { (5) } \\
\text { Japan (8) } \\
\text { South Korea (4) }\end{array}$ & \\
\hline $\begin{array}{l}\text { Comtois } \\
\text { and Dong } \\
(2007)\end{array}$ & $x$ & & $x$ & & $\begin{array}{l}1990- \\
2005\end{array}$ & & & & $x$ & & $\begin{array}{l}\text { Market } \\
\text { quotient } \\
\text { hinterland } \\
\text { regions }\end{array}$ & & & & & $\begin{array}{l}\text { Yangtze River Delta } \\
\text { (Shanghai vs. Ningbo) }\end{array}$ \\
\hline $\begin{array}{l}\text { Wang and } \\
\text { Cullinane } \\
(2008)\end{array}$ & $x$ & & & $x$ & & & & $x$ & & & $\begin{array}{l}\text { Multiple } \\
\text { linkage } \\
\text { analysis }\end{array}$ & & & $\begin{array}{l}\text { East Asia } \\
\text { (39) }\end{array}$ & & \\
\hline $\begin{array}{l}\text { Ducruet et } \\
\text { al. (2009) }\end{array}$ & & $x$ & & $x$ & $\begin{array}{l}1985- \\
2005\end{array}$ & $x$ & $x$ & & & & & $x$ & & $\begin{array}{l}\text { Northeast } \\
\text { Asia }\end{array}$ & North Korea & \\
\hline $\begin{array}{l}\text { Shinohara } \\
(2009)\end{array}$ & $x$ & & $x$ & & $\begin{array}{l}1995- \\
2008\end{array}$ & & & & & & $\begin{array}{l}\text { Port policy } \\
\text { discussion }\end{array}$ & & & & Japan & $\begin{array}{l}\text { Super hub ports: } \\
\text { Kobe/Osaka; } \\
\text { Nagoya/Yokkauchi; } \\
\text { Tokyo/Yokohama }\end{array}$ \\
\hline $\begin{array}{l}\text { Ducruet et } \\
\text { al. (2010b) }\end{array}$ & $x$ & & & $x$ & $\begin{array}{l}1996- \\
2006 \\
\end{array}$ & $x$ & & $x$ & & & $\begin{array}{l}\text { Single linkage } \\
\text { analysis }\end{array}$ & $x$ & $x$ & \begin{tabular}{|l|} 
Northeast \\
Asia \\
\end{tabular} & & $\begin{array}{l}\text { Super hub ports Hong } \\
\text { Kong and Busan }\end{array}$ \\
\hline $\begin{array}{l}\text { Lam and } \\
\text { Yap (2011) }\end{array}$ & $x$ & & & $x$ & $\begin{array}{l}1995- \\
2006\end{array}$ & $x$ & & $x$ & $x$ & $x$ & $\begin{array}{l}\text { Schedule } \\
\text { analysis }\end{array}$ & & & East Asia & $\begin{array}{l}\text { Shanghai, Busan, } \\
\text { Kaohsiung and } \\
\text { Ningbo }\end{array}$ & \\
\hline $\begin{array}{l}\text { Wang and } \\
\text { Wang } \\
(2011)\end{array}$ & $x$ & & & $x$ & 2008 & $x$ & & $x$ & & & Graph theory & & $x$ & World & $\begin{array}{l}\text { Hong Kong hub for } \\
\text { China/Korea/Japan } \\
\text { (15 ports); } \\
\text { Shenzhen hub for } \\
\text { South China and } \\
\text { Japan (9 ports); } \\
\text { Shanghai hub for } \\
\text { Yangtze River and }\end{array}$ & \\
\hline
\end{tabular}




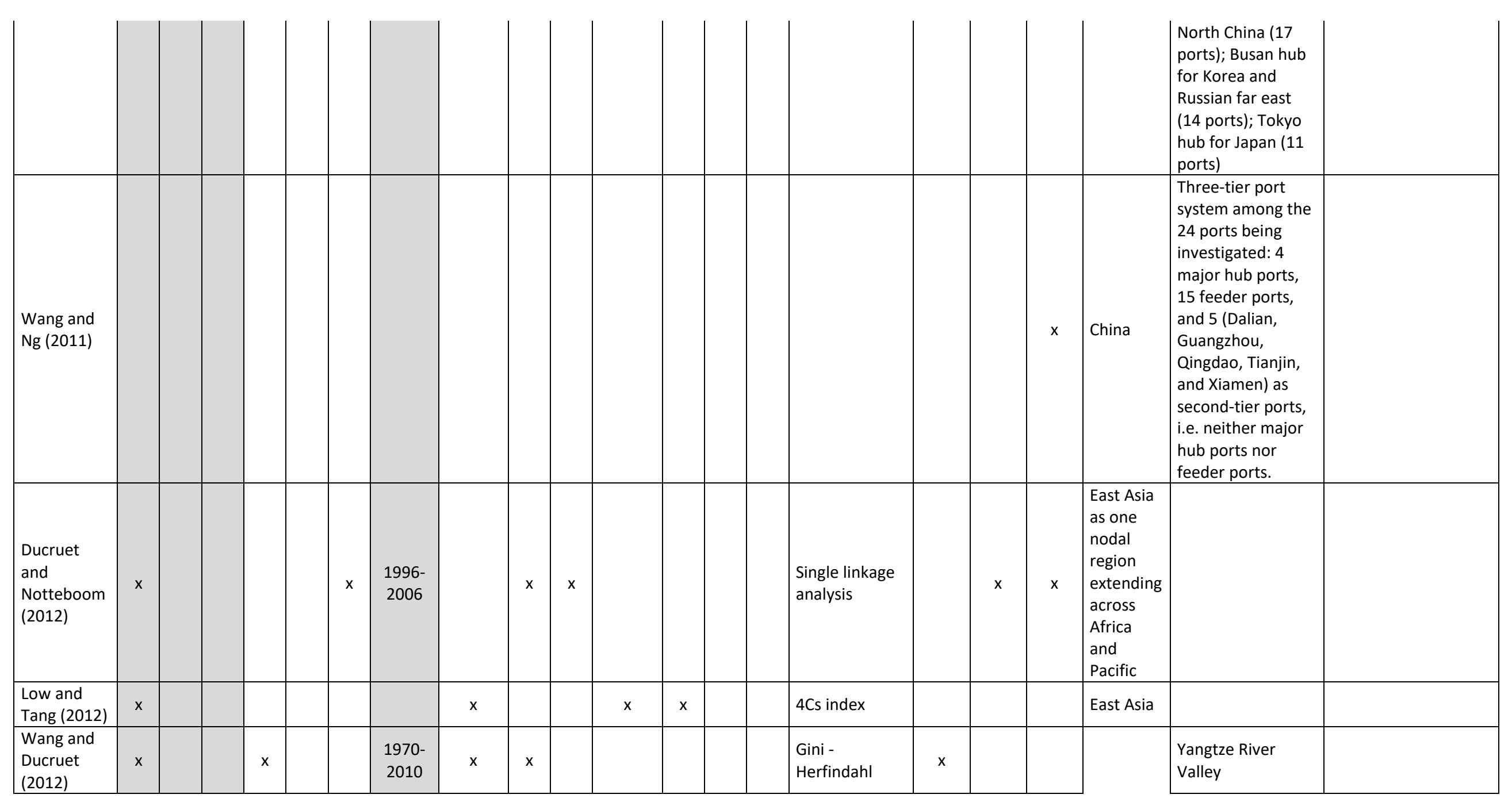




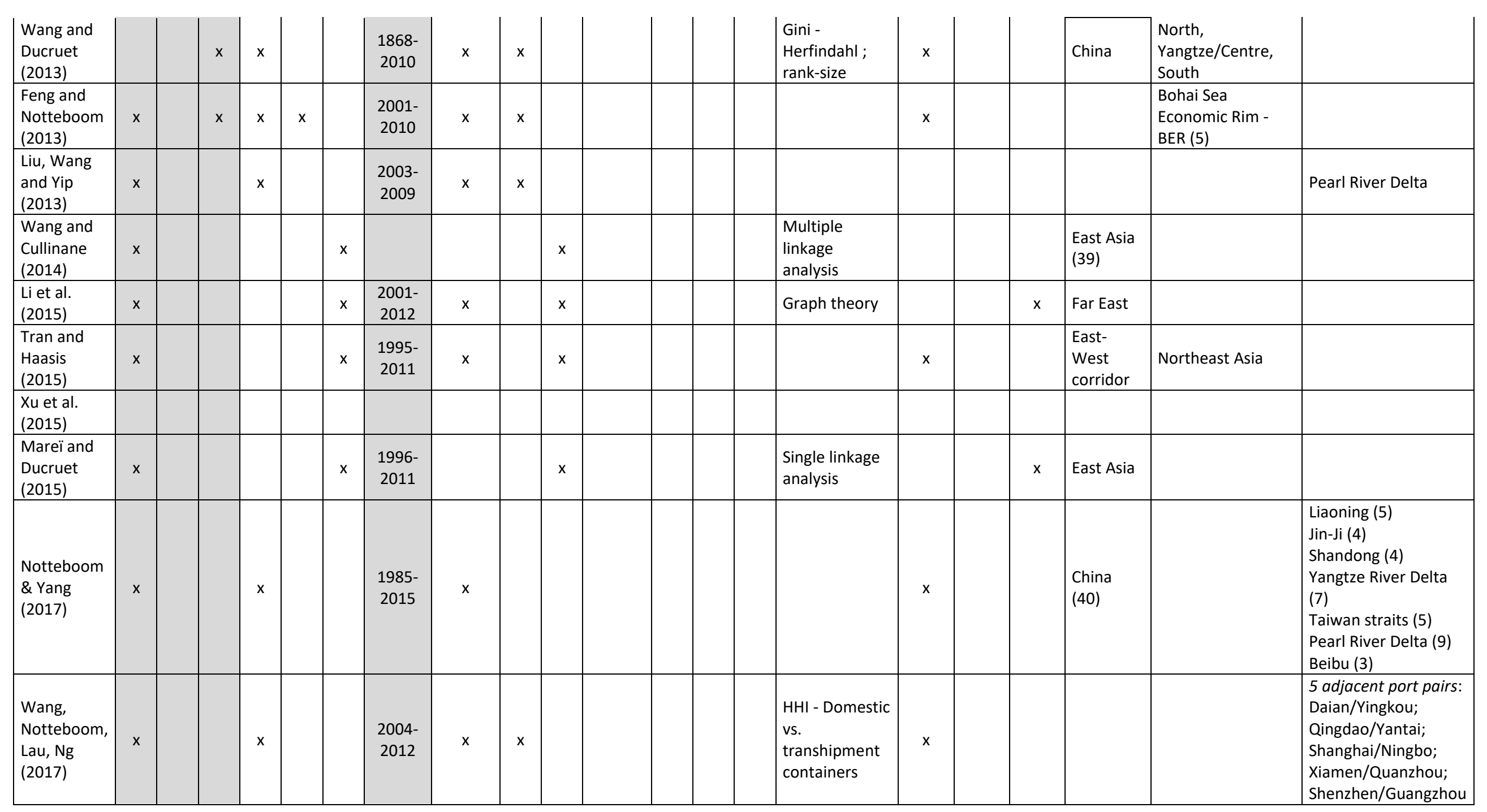




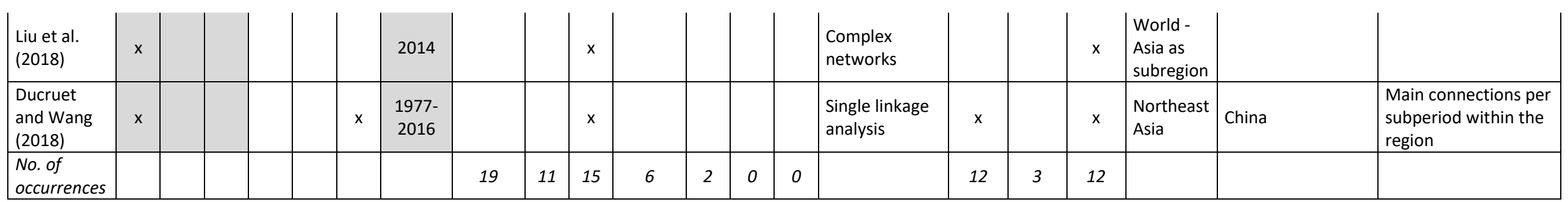

Table 2: Typology of selected works on port systems in Northeast Asia

Source: own elaboration

\begin{tabular}{|l|r|r|r|r|r|r|}
\hline & \multicolumn{3}{|c|}{ Nodes } & \multicolumn{3}{c|}{ Links } \\
\hline & 1996 & \multicolumn{1}{|c|}{2006} & \multicolumn{1}{c|}{2016} & \multicolumn{1}{c|}{1996} & \multicolumn{1}{c|}{2006} & \multicolumn{1}{c|}{2016} \\
\hline North Europe & 0.831 & 0.802 & 0.828 & 0.851 & 0.837 & 0.886 \\
\hline Northeast Asia & 0.879 & 0.848 & 0.817 & 0.904 & 0.882 & 0.869 \\
\hline
\end{tabular}

Table 3: Vessel traffic concentration in Europe and Asia based on the Gini coefficient, 1996-2016

Source: own elaboration based on Lloyd's List data 